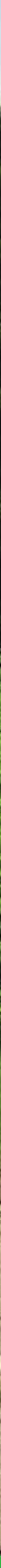

\title{
Exploratory study into possible applications of Asian knotweed
}

C.J. van Dijk, I.M. van der Meer, R.C.H. de Vos and A.K. van der Werf 



\section{Exploratory study into possible applications of Asian knotweed}

C.J. van Dijk, I.M. van der Meer, R.C.H. de Vos and A.K. van der Werf

WR is part of Wageningen University \& Research, the collaboration of Wageningen University and Wageningen Research Foundation.

Wageningen, August 2020

Report WPR-1004 
Van Dijk, C.J., I.M. van der Meer, R.C.H. de Vos and A.K. van der Werf, 2020. Exploratory study into possible applications of Asian knotweed. Wageningen Research, Report WPR-1004. 42 pp.; 9 fig.; 2 tab.; 35 ref.

This report can be downloaded for free at https://doi.org/10.18174/534063

Key words: Asian knotweed, Fallopia, train tracks, components, raw materials

(c) 2020 Wageningen, Stichting Wageningen Research, Wageningen Plant Research, P.O. Box 16, 6700 AA Wageningen, The Netherlands; T +31 (0)317 4807 00; www.wur. eu/plant-research

Chamber of Commerce no. 09098104 at Arnhem

VAT NL no. 8065.11.618.B01

Stichting Wageningen Research. All rights reserved. No part of this publication may be reproduced, stored in an automated database, or transmitted, in any form or by any means, whether electronically, mechanically, through photocopying, recording or otherwise, without the prior written consent of the Stichting Wageningen Research.

Stichting Wageningen Research is not liable for any adverse consequences resulting from the use of data from this publication.

Report WPR-1004

Cover photo: Asian knotweed along the train tracks (Photo: Christel Tijhuis) 


\section{Contents}

$\begin{array}{ll}\text { Summary } & 5\end{array}$

1

$\begin{array}{ll}\text { Introduction } & 9\end{array}$

$\begin{array}{lll}1.1 & \text { Motivation } & 9\end{array}$

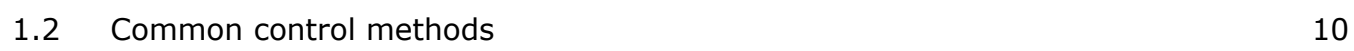

$\begin{array}{lll}1.3 & \text { Project goal } & 10\end{array}$

$2 \quad$ Asian knotweed background information

2.1 Species 11

2.2 Spreading $\quad 12$

2.3 Consequences $\quad 14$

$\begin{array}{llr}3 & \text { Desk study set-up } & 15\end{array}$

$\begin{array}{lrr}\text { Kick-off meeting } & 16\end{array}$

$\begin{array}{llr}5 & \text { Value from green refuse } & 17\end{array}$

$\begin{array}{lll}5.1 & \text { Plant compounds } & 17\end{array}$

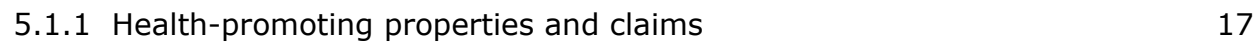

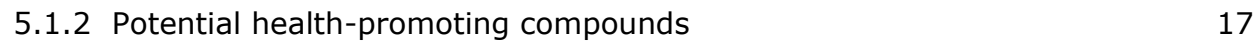

$\begin{array}{ll}5.1 .3 \text { Other components: } & 18\end{array}$

5.1.4 Human nutrition and supplements $\quad 20$

$\begin{array}{ll}5.1 .5 \text { Animal feed } & 21\end{array}$

$\begin{array}{lll}5.2 & \text { Raw materials } & 21\end{array}$

5.2.1 Biorefinery 21

5.2.2 Composting $\quad 25$

$\begin{array}{ll}5.2 .3 \text { Bokashi } & 25\end{array}$

5.2.4 Fermentation (biofuel) 25

5.2.5 Torrefaction, pyrolysis, incineration and gasification 26

$\begin{array}{lll}5.3 & \text { Other applications } & 27\end{array}$

$\begin{array}{ll}\text { 5.3.1 Phytoremediation } & 27\end{array}$

$\begin{array}{ll}\text { 5.3.2 Honey production } & 27\end{array}$

$\begin{array}{ll}\text { 5.3.3 Design objects } & 27\end{array}$

$\begin{array}{llr}6 & \text { Volume streams } & 28\end{array}$

$\begin{array}{lll}6.1 & \text { Biomass } & 28\end{array}$

6.2 Asian knotweed along the tracks $\quad 28$

6.3 Common management methods around the tracks $\quad 29$

$\begin{array}{llr}7 & \text { Evaluation } & 32\end{array}$

$8 \quad$ Conclusions and recommendations $\quad 34$

$\begin{array}{ll}\text { References } & 37\end{array}$

Annex $1 \quad$ Elimination methods for Asian knotweed (general) 39 



\section{Summary}

Invasive exotic plant species do not grow naturally in the Netherlands. Brought to this country by human activities, they can damage the environment, economy, safety and the health of people and animals. Indigenous to Japan, China, Taiwan and Korea, Asian knotweed is a good example. A perennial plant that can grow up to three to four metres high, its stems grow from long, heavily branched and fast-growing rootstocks underground. The presence of knotweed results in the loss of indigenous flora, causes damage to capital goods, is a threat to safety and leads to tens of millions of euros in costs every year.

ProRail asked Wageningen UR to perform an exploratory study into the possible uses/applications of Asian knotweed. If parts of the plant could be useful, control might be commercially and technically more attractive and stimulate new developments. This would in turn contribute to the sustainability goals of ProRail. The results of this study show that knotweed is used for various purposes in Asia.

\section{Human nutrition, medicinal applications and supplements}

Knotweed is used as a traditional (folklore) medicine in Asian countries. Medicinal or health-related effects have been proven in various human cell lines and lab animals. These are largely attributed to the phenolic compounds resveratrol and emodin, of which high concentrations are mainly found in the roots. Unfortunately, there is no scientific proof for their effectiveness in humans.

Knotweed is also used in Asian cuisines. Due to their mildly acidic flavour, young shoots are eaten like asparagus or as a replacement for rhubarb. Asian knotweed also contains components that probably could be used for the production of resins and colourants.

The fact that knotweed is used in many Asian countries does not automatically mean the same applies to Europe. Food that was not consumed in the EU to a significant degree before 15 May 1997 is considered as 'Novel Food' and cannot be marketed before authorisation has been granted by the European Food and Safety Authority (EFSA). To obtain that authorisation requires scientific and technical proof that the new food can be consumed safely and has no harmful effects on those who consume it. In addition, it must be shown that the 'new' crop or product can be produced safely. This means that the cultivation has to be performed under controlled and hygienic conditions.

Asian knotweed that grows in the wild along train tracks by definition does not meet this EFSA condition for cultivation. Moreover, it is known that knotweed can absorb a relative high amount of heavy metals from the soil and this is probably the case in locations near the tracks. This makes the option of using Asian knotweed for human nutrition, medicinal applications or for the supplement market in Europe unlikely.

\section{Animal feed}

The direct application of biomass in commercial animal feed is also subject to requirements related to controlled cultivation in hygienic conditions. If biomass first undergoes an extraction process, however, and only the required pure extracted component, such as protein, is added to animal feed, the condition for controlled cultivation does not apply. 


\section{Biorefinery}

Biorefinery techniques offer the possibility of using biomass as a raw material for the production of protein, fibres and sap from which phosphate, sugar, minerals and salt can be extracted. The development of this technology is currently ongoing, especially for the processing of (roadside) cuttings and biomass resulting from water management. Concrete examples of products produced from biomass on an experimental scale are paper and cardboard, insulation material, peat replacement, bio-composite for tree supports, shoring material, barriers and simple garden furniture. It is also processed in concrete and tiles, stairs and reinforcement plates for walking or biking trails. Pre-processed bamboo is used as a construction material. The application of bio-based products produced from its 'own' green refuse contributes to ProRail's sustainability goals. Specific examples of biorefinery with refuse from Asian knotweed have not yet been found. This does not mean that these developments could not create opportunities for the processing of knotweed, possibly combined with other green refuse resulting from track management. The way that cutting is currently managed around the tracks, primarily focused on cost-efficient logistics, would have to be reorganised.

\section{Energy recovery}

Asian knotweed supplies a relatively high amount of biomass with an energy value similar to dry wood chips and wood pellets. Combined with other green refuse streams, knotweed biomass could be suitable for energy recovery via fermentation or incineration as pellets. Harvesting the knotweed biomass above ground on a yearly basis would keep the growth locations intact, but wouldn't contribute to the elimination goals.

\section{Phytoremediation}

Phytoremediation with Asian knotweed is a proven technology to immobilise or remove pollution from the soil and especially applies to zinc, cadmium and copper-polluted soils. The principle of phytoremediation is based on the periodic removal of plant parts above ground in which pollution has amassed. The growth location must generally remain intact for a longer period to do so, which is not in line with ProRail's elimination goal. Existing growth locations of knotweed on polluted soil could be preserved to remediate the soil and removed at a later date once the soil levels have sufficiently recovered. There would be additional benefits if the plant parts above ground were harvested periodically, taking into account the accumulation of heavy metals, and used in a practical way.

\section{Volumes}

The amount of biomass that can be obtained from knotweed rootstocks is comparable to that of potato tubers: approximately 15 tonnes of dry material per ha. In the Netherlands, however, some 80,000 hectares of consumption potatoes were grown in 2019 (CBS) while the acreage of knotweed around the train tracks is estimated at around 10 ha. Based on the relatively small acreage of Asian knotweed, it is unlikely that viable processing can be set up. The dispersed growth locations, the current limited area and available equipment would result in relatively high 'harvesting' costs. A better business case could be established by combining possible applications of biomass and new technologies in a smart way. Options include:

- Scaling up the harvestable volume of knotweed via improved surveying along the tracks and better collaboration with other managers of land with knotweed, or processing in combination with other green refuse such as roadside cuttings;

- Using the knotweed locally to remediate polluted soil combined with the processing of resulting plant material into bio-based materials and products, taking into account the amassed heavy metals. This could be realised by joining ongoing initiatives for the processing of green refuse such as (roadside) cuttings, bamboo or elephant grass;

- Improving the 'harvesting techniques' for removing rootstocks and plant parts above ground. This could prevent issues and costs related to the stability and settlement of the soil, disruption of the water management around the tracks, and the unintentional further spreading of the knotweed due to earth movement. 


\section{Recommendations}

- Developments in the field of biorefinery create opportunities for the processing of knotweed in, for example, animal feed, possibly combined with other green refuse resulting from track management. We recommend joining ongoing initiatives.

- Fibres from green refuse are suitable as raw material for specific products like paper and cardboard, building materials and for use in constructions (analogous to bamboo). It is recommended to (have third parties) develop products from green refuse resulting from the current management around the tracks as this would contribute to ProRail's sustainability goals.

In addition, we recommend research into whether fibres from knotweed have the same properties and applications as fibres from (roadside) cuttings, bamboo and elephant grass. If so, these fibres could also be used in specific products.

- Find out whether energy recovery is possible and profitable by processing knotweed into fuel pellets or via fermentation, possibly combined with other green refuse streams.

- Knotweed must firstly be harvested before it can be applied. This harvest currently often involves large scale earth-moving activities, including all the related risks, and is relatively expensive. New technologies that involve as little earth-moving activities as possible are required. We recommend finding out if there are any developments in the field of sensor technology, robotics and autonomous vehicles in agriculture, for instance, which offer opportunities to optimise the process.

- Research whether the absorption of heavy metals by Asian knotweed can play a role in the remediation of soil pollution around the tracks (phytoremediation). Existing growth locations on polluted soils can be kept intact for phytoremediation purposes, while knotweed can be removed from unpolluted soils. Deliberately planting knotweed on polluted soils along the tracks to enable soil remediation is not recommended.

- Even if a useful application of Asian knotweed is found, it will remain difficult to establish a definitive business case based on the current acreage. Options to improve the business case include upscaling biomass and combining applications by:

- Increasing biomass volumes by cooperating with other terrain managers such as RWS, municipalities, provinces and district water boards, or seeking out international partnerships.

- Processing knotweed refuse in combination with other green refuse streams to create more volume. A condition will be reorganising the current cutting methods, which are primarily focused on cost-efficient logistics. 


\section{Introduction}

\section{$1.1 \quad$ Motivation}

Invasive exotic plant species are species that do not grow naturally in the Netherlands, were brought here via human actions and may damage the environment, economy, safety or health of people and animals. Transport, trade and tourism are the main routes. Exotic species can be brought here accidentally, for instance during transport, or intentionally via the sale of exotic pond and garden plants. A small proportion of these exotic species is able to survive in our environment and is considered to be invasive when it starts to rapidly multiply.

An invasive exotic variety designated as a major pest by ProRail is Asian knotweed (Fallopia spp.). Knotweed is indigenous to Japan, China, Taiwan and Korea. It is a perennial plant that can grow up to three to four metres high. The stems grow from long, heavily branched and fast-growing rootstocks underground. The variety was brought to the Netherlands from Japan as a garden plant around 1830 and has since spread throughout large parts of Europe. The knotweed species grow in a variety of environments in the Netherlands, including urban areas, rail embankments, vacant lots, roadsides (and median strips of motorways), river groynes, forest edges, along streams and on dykes.

Locally, exotic species often spread along (main) transport routes such as motorways, railways, channels and rivers (Hulme et al., 2009; 2008). Knotweed mainly grows in the green strips along the tracks and on rail embankments (Figure 1). Its presence along the tracks results in the loss of indigenous flora, causes damage to capital goods, is a safety risk (e.g., grows into relay boxes and accelerates the erosion of embankments) and leads to tens of millions of euros in control costs every year. Fragments of knotweed can be spread further along the tracks by trains and in the air to create new hotbeds.

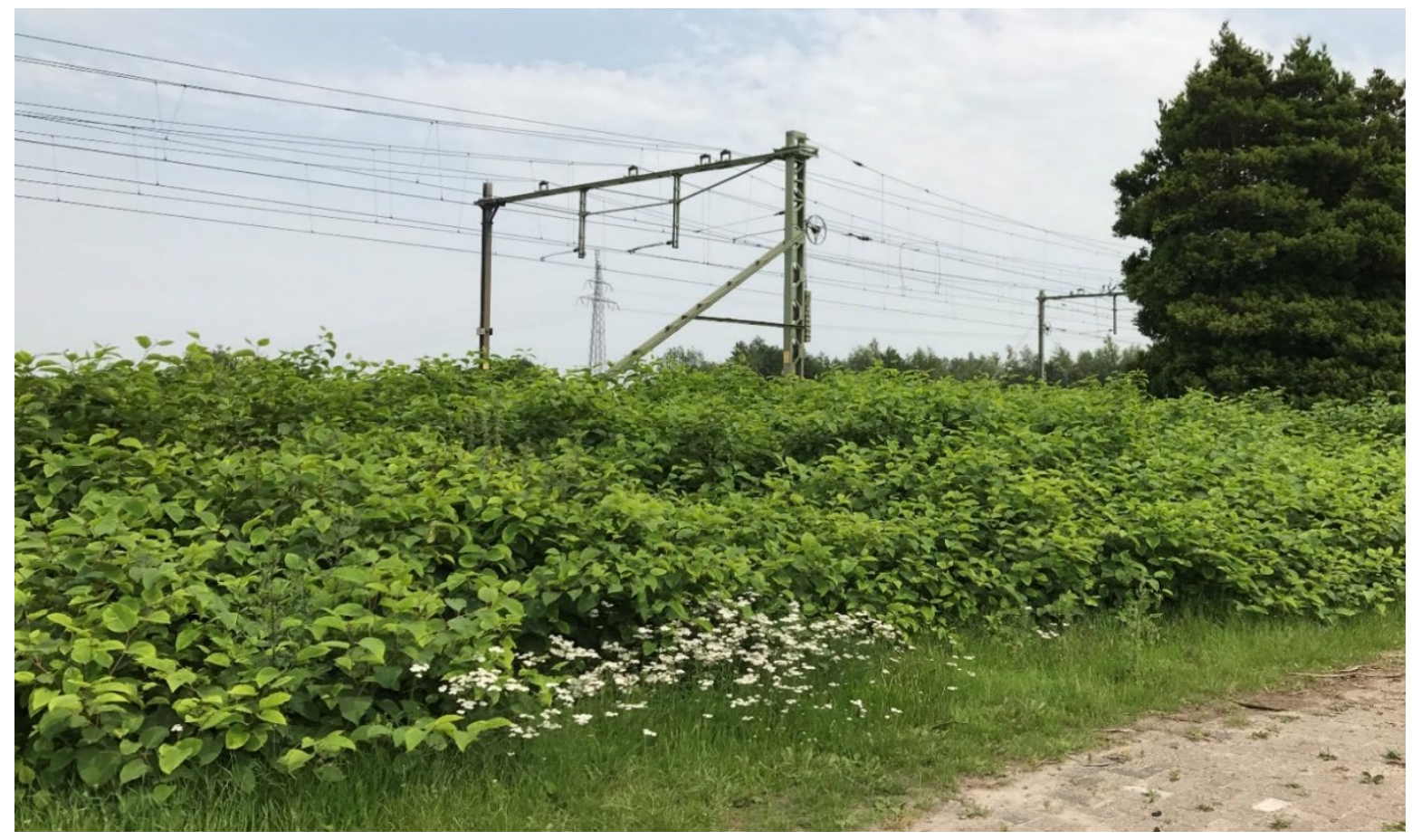

Figure 1 Asian knotweed along the tracks (Photo: Christel Tijhuis). 


\subsection{Common control methods}

Various methods are currently available to control Asian knotweed, including mechanical, thermal, chemical and organic. Each method has specific benefits and disadvantages and their effectiveness varies greatly. The most common control methods, like cutting and hot water, are aimed at regularly removing the plant parts above ground. This approach does not usually have the desired effect in the long term, however, as the underground roots remain intact. The rootstocks contain so-called 'sleeping' buds which are activated after the stems are clipped and from which new stems grow. They also produce 'real' roots for the absorption of water and nutrients. Multi-year applied research into methods such as cutting and grazing has shown that the best result which can be achieved by these methods is control of the knotweed hotbed and shorter and thinner stems in the long term, although these do not lead to complete elimination (Oldenburger et al., 2017). New control methods such as hot water or electricity also do not appear to result in the complete elimination of hotbeds, despite frequent application. Biological control methods in development (psyllids and leafspot fungus) are primarily focused on the plant parts above ground. While methods focused on rootstocks offer more perspective for effectively controlling knotweed, techniques that directly affect the rootstocks are unavailable, except for large-scale earth removal or the application of herbicides.

Large-scale earth removal on growth locations is effective, but also generates a large volume of knotweed-infected soil for which we currently have no effective processing methods, except dumping or thermal cleaning which is not very sustainable and relatively expensive. Moreover, earth removal is not possible at many locations, and creates a major risk of further spread of the knotweed via equipment and soil transportation. Using herbicides (such as glyphosate) is effective (Oldenburger et al., 2017) and legally allowed, but no longer applied by most terrain managers due to social resistance to the use of herbicides. Moreover, the use of these products is also being increasingly restricted by law.

A brief description of the most common methods for controlling Asian knotweed and an estimate of their effectiveness can be found in Annex 1. Experience has taught us that no one method can be considered most suitable; the best results are achieved by combining control techniques and applying them over a longer period (years).

\subsection{Project goal}

ProRail manages the infrastructure of the main rail network in the Netherlands, including the green areas around the tracks. Asian knotweed is fairly common along the tracks and on rail embankments. Most management contracts do not specifically describe the way knotweed stands should be handled leaving contractors to determine the approach. In most cases they cut the growth, possibly combined with the removal of the knotweed refuse. Pilots projects are being performed with hot water and electricity.

ProRail asked Wageningen UR to perform an exploratory study into the possible uses/applications of Asian knotweed. If (parts of) the plant could be useful, controlling the plant might be commercially and technically more appealing, which in turn would stimulate new developments. In addition to types of reuse and useful applications like biobased materials, this may also involve new harvesting methods that have less impact on the environment than the current ones.

Topics included in the desk study include:

- Use as a raw material (biomass);

- Construction material (fibres, replacing bamboo or wood);

- Perspectives for the use of health-promoting components (health claims) and novel food;

- Any other applications resulting from the study. 


\section{Asian knotweed background information}

\section{$2.1 \quad$ Species}

The most well-known Asian knotweed is Japanese knotweed (Fallopia japonica), which is indigenous to Japan, China, Taiwan and Korea. The variety was brought to the Netherlands from Japan as a garden plant around 1830 (Figure 2). It spread throughout the Netherlands and large parts of Europe from the Hortus botanical garden in Leiden. The Netherlands only started removing the plant on a large scale after 1950 as a result of the dumping of garden waste with plant residue. The variety can now be found in almost all of Northwest Europe. The plants are found in a large range of very nutrient-poor and/or dry environments such as rail embankments, vacant lots, roadsides (and median strips of motorways), river groynes, forest edges, along streams and on dykes. It fares well on so-called disturbed soils, such as after digging activities or the dumping of knotweed-infected soil.

In addition to Japanese knotweed (Fallopia japonica, synonyms: Reynoutria japonica, Polygonum cuspidatum) the Netherlands is also home to giant or Sakhalin knotweed (Fallopia sachalinensis, synonyms: Reynoutria sachalinensis, Polygonum sachalinense) and Bohemian knotweed (Fallopia $x$ bohemica). The latter knotweed is a hybrid between $F$. japonica and $F$. sachalinensis, and increasingly found in the Netherlands. The species together are commonly known as Asian knotweed. This report uses the term Asian knotweed for these species, unless indicated otherwise. With regard to the control and effectiveness of control methods, there is little difference between the individual species.

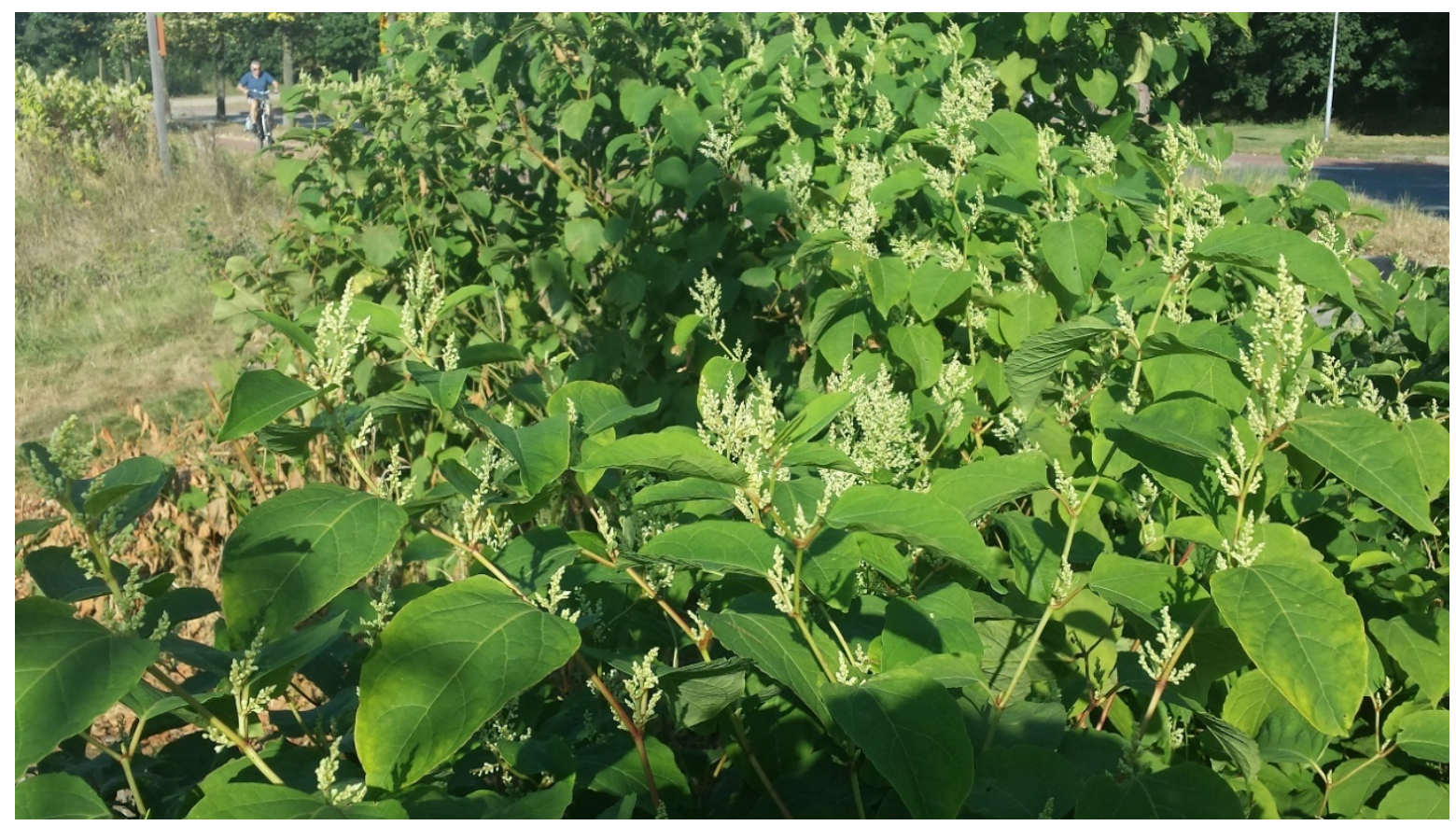

Figure 2 Japanese knotweed (Fallopia japonica) in flower (August).

Knotweed is a perennial plant with long, heavily branched rootstocks underground. The majority of the rootstocks are in the layer down to $80-100 \mathrm{~cm}$ below ground, and sometimes deeper. The rootstocks can vary in thickness between $5 \mathrm{~mm}$ to fist thickness (Figure 3). At old growth locations, the thickest stems often grew from one large central 'stalk'. In spring, many closely knitted stems with a large leaf surface grow rapidly from knots on the rootstocks. Depending on the location, the stems can grow up to three to four in height. The plants do not grow as well in very shady spots. They bloom with 


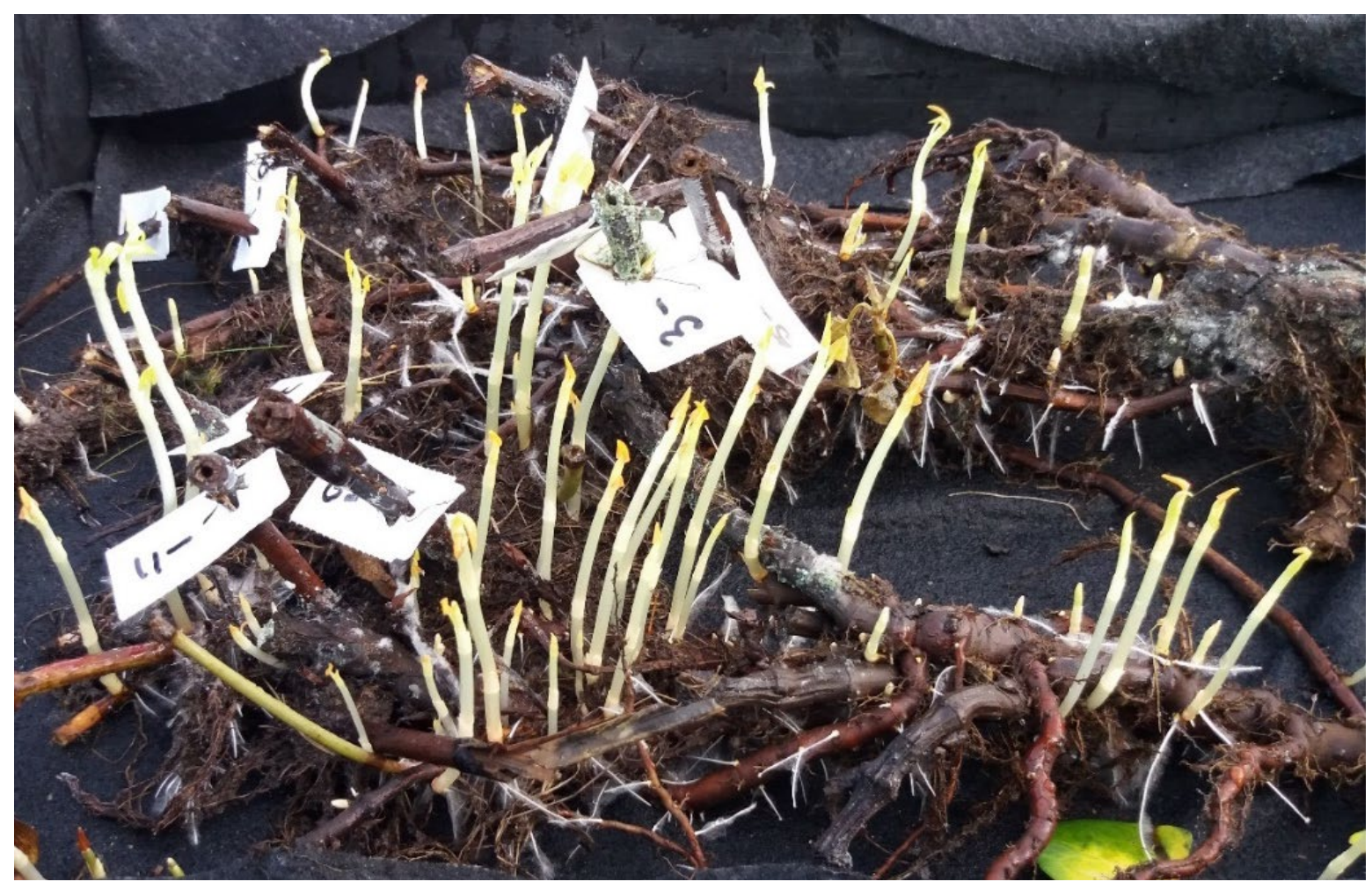

Figure 3 Vital rootstocks (underground roots) three days after being dug up. The new upward shoots and the white downward roots are clearly distinguishable.

\subsection{Spreading}

Human activities are the largest risk for the variety spreading over greater distances. Examples include the transportation of root and stem fragments after machine-cutting activities and the moving of soil which contains parts of roots or stems. Leaving cuttings of knotweed lying around is also a risk for further spread due to cross-contamination. Moreover, leaving the cuttings behind does not contribute to improving biodiversity as this will not help realise the desired reduction of organic matter in the soil. Fragments of rootstocks and/or stems above ground of less than $1 \mathrm{~cm}$ can grow to become new plants. If these fragments end up on the ground elsewhere, new plants will develop. Young, individual plants are relatively easy to remove, but established hotbeds are very difficult to remove. The stems that die in winter do not present a risk for further spreading.

In the Netherlands, Japanese knotweed is increasingly found with germinable seeds. In many cases, Chinese fleecevine is the source of the pollen. The current chance of germination for seeds of the hybrid between Japanese knotweed and Chinese fleecevine (Fallopia $\times$ conollyana) is small; the hybrid does not appear to be very competitive and has not been found in the wild in the Netherlands. The fact that the seeds are formed, however, generates two new dangers:

- Seed formation results in another reproduction and spreading method in addition to spreading via root and stem fragments, and seeds are easily spread by wind and water, allowing the knotweed to spread even faster.

- Generative reproduction increases the genetic variety of the knotweeds, allowing them to adapt faster and become more competitive. To prevent an increase in genetic diversity, the control of male plants of Japanese knotweed, as well as the hybrid knotweed and Sakhalin knotweed, must be given a high priority (Leferink, et al., 2020). 
For most plant species, the majority of the roots are in the layer down to approx. $100 \mathrm{~cm}$ below ground. Variety-specific properties and soil build-up also play a role. The rootstocks of Asian knotweed are largely in this top soil layer but may occasionally grow deeper. A specific rail-related example involves the rail embankment by Kop Weespertrekvaart in Amsterdam which was known to contain Asian knotweed. Due to the different layers in the soil, the knotweed rootstocks were almost exclusively found in the top $80-100 \mathrm{~cm}$ of the embankment, in the covering layer (Figure 4). While the sand bed below did not contain rootstocks, it did contain 'real' roots of the knotweed for absorbing water and nutrients. These 'real' roots are not of interest in the framework of control as they don't produce new shoots (Van Dijk, 2018). Knotweed rootstocks can be recognised by their characteristic orange colour (Figure 5).

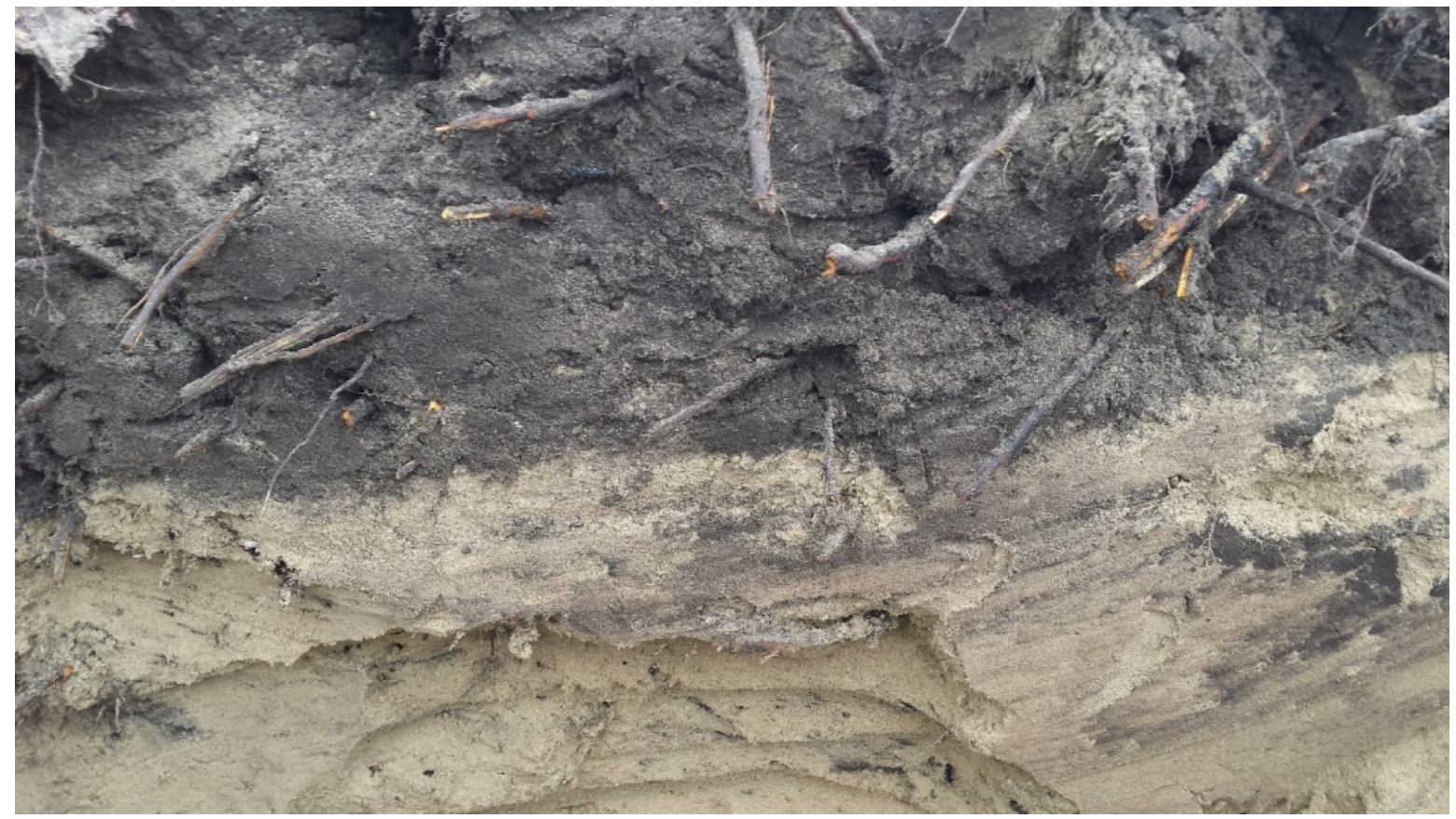

Figure 4 Rootstocks of Asian knotweed in the dark covering layer of the rail embankment at Kop Weespertrekvaart, Amsterdam.

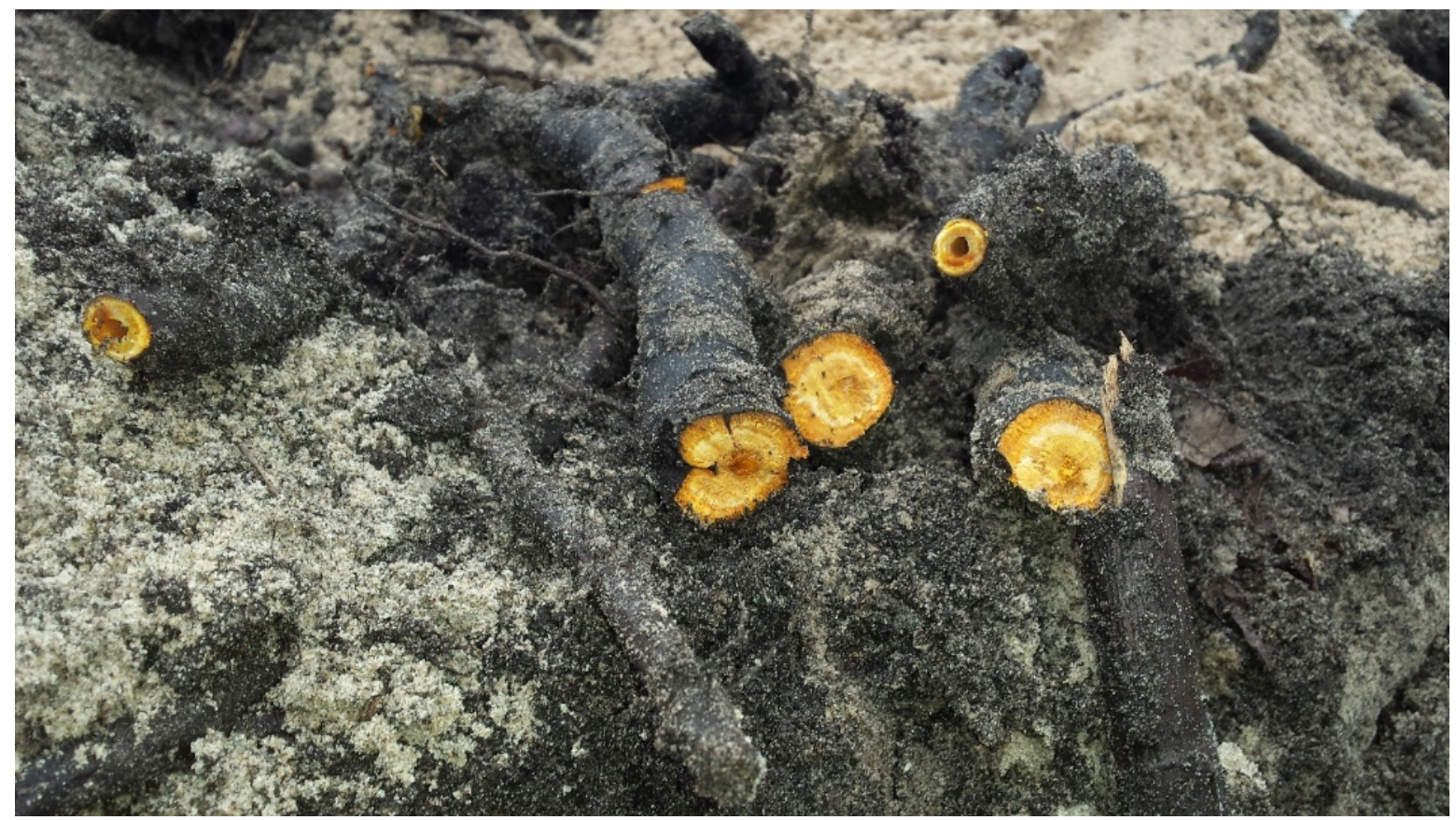

Figure 5 Rootstocks of Asian knotweed and their characteristic orange colour. 


\subsection{Consequences}

The fast growth and dense leaf cover of Asian knotweed displace indigenous plant species, and the rootstocks proliferate and cause damage to buildings, pipelines and infrastructure. River banks and embankments become more unstable and sensitive to erosion as the overgrowth is displaced, especially in winter when knotweed dies above ground and leaves the soil uncovered.

The presence of Asian knotweed results in extra costs for management activities such as monitoring, staff education and after-care. Extra costs can also be generated by precautionary measures to prevent further spreading such as machine cleaning, soil cleaning and checking the soil for the presence of Japanese knotweed. This involves tens of millions of euros a year in extra costs paid by both public (e.g., municipalities and district water boards) and private parties (in sectors such as infrastructure, project development, civil engineering).

Investing in tackling Asian knotweed can prevent the situation in the Netherlands from becoming like that in the UK, where the problems are so large that they lead to a reduction in value of construction sites and real estate that contain knotweed. 


\section{Desk study set-up}

A kick-off meeting was organised prior to the study to exchange ideas and opinions with representatives from ProRail and Wageningen UR experts in the field of plant metabolites, the biobased economy and the management of invasive exotic species.

To explore where the opportunities related to the (high-quality) processing of plant material from Asian knotweed lie, we looked for existing specific applications of Asian knotweed in (scientific) literature. From a broader perspective, we examined a specific sub-stream in the bulk of green refuse generated during track management. Developments in the field of processing cuttings from road and track-side vegetation or green refuse from water management may provide leads. There are various ongoing studies and initiatives looking for high-quality methods to process and market green refuse at a high-quality. Where relevant, the initiatives were included in this study.

Various sources and databases were used to collect information on the uses and applications of knotweed. After first consulting internal documentation we looked for additional information via search engines and databases, including Google Scholar, Wageningen Library and Groen Kennisnet. 


\section{$4 \quad$ Kick-off meeting}

A kick-off meeting with representatives from ProRail and Wageningen UR took place on

18 February 2020. The meeting resulted in ambitions, ideas and perspectives that were included in the research.

- ProRail has an ambition to fully eliminate Asian knotweed in the long term. It realises that this cannot be realised in the short term and will require efforts over a number of years. Implicitly, this means that growth locations are not preserved to 'harvest' knotweed;

- An important aspect is sustainability as ProRail seeks to showcase its efforts toward circularity, reduce its $\mathrm{CO} 2$ footprint and so on. It is therefore looking for options to make specific rail products, such as sleepers, sound barriers and energy units from biobased material;

- Management is currently seen as a cost item. Could the control of knotweed be more commercially and technically appealing if considered from a different perspective than usual and could this stimulate new developments? The study may boost the process to establish concrete innovations over time;

- Developing useful applications combined with the 'elimination' management goal is not feasible in the long term. There may be a better perspective in combining the digging out of rootstocks (and which techniques are available in this framework?) and possible applications of the rootstocks. This would be in line with the elimination goal;

- Operational costs are not the main aspect: the main goal is to identify options such as the stimulation of biobased developments (materials/bio-composite) (to be continued in follow-up research);

- Options with good perspectives can be taken up in collaboration with other (large) terrain managers (such as Rijkswaterstaat). 


\section{$5 \quad$ Value from green refuse}

The high-quality reuse of waste and residual streams is attracting lots of interest. The goal is to create an economy in which biotic raw materials, among others, are efficiently used and optimally reused. This includes a strong focus on green waste streams resulting from the management of green facilities and (roadside) vegetation. In this framework, green refuse such as roadside cuttings and pruning refuse are no longer seen as waste but as a potential resource that can be applied in a useful way. In addition, green refuse does not compete with food production on high-quality agricultural land. This changes the perspective as - just like grain, maize and grassland have economic value in the current linear economy - green refuse will have economic value in the circular economy.

The goal of valorising green refuse usually consists of two aspects:

- Compensating for management costs by applying biorefinery and other techniques that result in added value (monetary);

- Increasing sustainability by reducing the emission of greenhouse gases, closed cycles/circularity, creating environmental value, etc.

\subsection{Plant compounds}

Asian knotweed is known to include edible parts and contain compounds that are said to have healthpromoting properties. Plants that grow in the wild in an uncontrolled way and were not eaten on a large scale before 1997 cannot be commercially marketed as an ingredient or food product under EU regulations. The rules are even stricter for medicinal use. This means that this route can be forgotten as a possible application in the short term and under these 'growth conditions'. The same applies more or less to animal feed, in which case hygienic cultivation is especially important. The rules for extracting supplements are somewhat less stringent. ProRail indicated that it would like to receive more information on this aspect to have a comprehensive overview of the (im)possibilities. For this reason, these aspects are detailed further in this desk study.

\subsubsection{Health-promoting properties and claims}

In Asian countries, knotweed is used as a traditional (folklore) medicine. The dried root of knotweed is known in Chinese medicine as 'Hu Zhang' and is one of the medicinal herbs referred to in the Pharmacopoeia of the People's Republic of China. This handbook of medicine composed by the Chinese Ministry of Health is recognised by the World Health Organisation (WHO) as the official Chinese Pharmacopoea. Knotweed, or Hu Zhang, is not included in the European Pharmacopoea, however. Both knotweed rootstocks and above-ground plant parts contain a variety of plant-specific compounds, also known as phytochemicals (see below). Medicinal extracts are obtained by extracting the phytochemicals from the dried and finely ground plant parts from above or below ground by adding hot water ('herbal tea') or an alcoholic solution ('tincture').

In China, knotweed extracts are often used in combination with other herbs as traditional medicine for a plethora of issues or symptoms, including bowel problems, coughing, arterosclerosis, gallstones, menopausal issues, snake bites, burns and wounds, infections and allergic reactions. It is also stated that knotweed extracts have antiviral and anticancer activities (Zhang et al., 2013; El-Readi et al., 2016). Various, mainly Asian, university research groups have shown a variety of health-related effects in human cell cultures (in vitro) and lab animals (in vivo). Among other things, it is reported that extracts from knotweed slow down the growth of various viruses and bacteria that are harmful to people, and have anti-inflammatory and wound-healing properties in mice and rats. The main components of knotweed (see below) in a pure form have anti-inflammatory effects and give lab animals an improved functioning of their immune system, reduced risk factors for cardiovascular disease, protection of the nervous system and brain cells, and/or improved recovery of skin wounds. 
In addition, the crude extracts of certain individual components purified from knotweed show various chemo-protective effects in some cancer cell lines, including leukaemia, breast cancer, prostate cancer, pancreatic cancer, bowel cancer and liver cancer cells.

All these potentially therapeutic or health-promoting effects of knotweed have so far been mainly studied in human cell lines or animal testing. The concentration of plant extracts in which effects are found in cell lines are often unnaturally high, however. In addition, the bio-availability and metabolism of many plant compounds in human is different than in (often genetically identical and cultivated under controlled conditions) animal models like mice, rats and rabbits. For humans there is currently very little scientifically substantiated evidence for the proposed therapeutic or health-promoting effects of knotweed: hardly any intervention or clinical studies have been performed with these supplements as is common for regular medicine and functional nutrients in Europe. A relatively small intervention study in the USA, with 20 healthy individuals, indicated that the blood of the 10 participants who were given a daily dose of 200 milligrams of knotweed extract for a period of six weeks had on average a better suppression of inflammatory reactions from week 3 onwards than the 10 participants who were given a placebo (Ghanim et al., 2010). This suppressing effect may be favourable for inflammation-related processes and syndromes. There have been multiple intervention and clinical studies related to health with pure resveratrol, one of the main components of knotweed which also occurs in wine (summarised in Berman et al., 2017 and Ramirez-Garza et al., 2018, among others); also see below.

\subsubsection{Potential health-promoting compounds}

While no scientifically substantiated proof for beneficial health effects in humans has been established to date, knotweed does contain a significant series of potential bioactive compounds. The main compounds and their pharmaceutical activities are summarised in various articles, including one by Zhang et al., (2013), and discussed further below. The indicated amounts in the plant materials are only indicative, as the actual values depend largely on the growth conditions, plant development stage and the way the chemical analysis is performed.

Resveratrol is a phenolic antioxidant that is mainly known from red wine, with the largest levels in the plant kingdom being found in the rootstocks of knotweed; knotweed is therefore the richest known source of this potentially health-promoting plant material. Knotweed-based tea, common in Japan, could be an alternative source of resveratrol for people who do not or cannot drink red wine. Biochemically, resveratrol belongs to the large group of flavonoids or polyphenols. Resveratrol is one of the many so-called phytoalexins: plant defence compounds against fungi, bacteria and viruses. Resveratrol is found in various products such as grapes (skin and seed), peanuts, cacao, eucalyptus and pine nuts, and, as said, especially in Asian knotweed. The levels of free resveratrol in knotweed rhizome can be as high as 2 grams per $\mathrm{kg}$ of fresh weight (in red wine, this is 2 to 12 milligrams per litre). In addition to this free form, resveratrol in knotweed rootstocks, as in grapes, is also present in a conjugated form with glucose: this resveratrol-glucoside is known as polydatin or piceid. The amount of polydatin in rootstocks can be as high as 3 grams per $\mathrm{kg}$ of fresh weight, which is equivalent to 1.5 grams of resveratrol units in bound form; this totals around 3.5 grams of resveratrol per $\mathrm{kg}$ of fresh weight of rootstocks. Exact levels of both resveratrol and polydatin depend on aspects such as growth location and season; the highest levels were measured in spring (Kurita et al., 2014). The levels of resveratrol and polydatin are nearly a thousand times lower in the leaves (up to 5 micrograms per $\mathrm{kg}$ of fresh weight) and ten thousand times lower in stems compared to what the rootstocks contain. Another study with (freeze)dried Polygonum multiflorum plants indicates 25-50 grams of polydatin per $\mathrm{kg}$ in dry root weight, $1-6 \mathrm{~g}$ per $\mathrm{kg}$ in stems and less than $2 \mathrm{~g}$ per $\mathrm{kg}$ in leaves (Rui et al., 2018).

There has been a lot of research worldwide into the potential health effects of resveratrol in humans, especially using cell lines (in vitro). There are reports on antimicrobial, anticancer, antioxidant and anti-inflammatory activities and on the protection of brain functions and veins. Resveratrol even slows down inflammation, in vitro, caused by the Middle East Respiratory Syndrome virus MERS-CoV, a coronavirus similar to SARS-CoV, the predecessor of Covid-19 (=SARS-CoV-2). 
Unfortunately, results of in vitro studies with cell lines or lab animals are difficult to translate into medicinal or health-related effects in humans. As applies to most phenolic plant compounds, the bioavailability of resveratrol, and thus the circulation in the body and potential pharmaceutical effects, strongly depends on the food matrix or formulation of the food supplement and the individual composition of the intestinal flora. Intervention studies performed with resveratrol mainly involved healthy people and indicated that taking (pure) resveratrol is safe up to 5 grams a day, but also that the results regarding health effects are contradictory (Ramirez-Garza et al., 2018). Clinical studies with resveratrol are mainly focused on disease in which damage by oxidation processes and inflammatory reactions play an important role, and in which antioxidants such as resveratrol could potentially have a positive effect (Berman et al., 2017). These clinical studies show that a resveratrol supplement of 1 to 2 grams a day may be favourable for Alzheimer patients and patients with cardiovascular disease and diabetes II, but that it may also have negative effects on patients with certain types of cancer and nonalcoholic fatty liver disease. All research groups clearly indicate that more research is required before any medicinal or health-promoting claims for (pure) resveratrol can be made.

Emodin, or 3-Methyl-1,6,8-trihydroxyanthraquinone, is an anthraquinone, another class of phenolic antioxidants. The group of anthraquinones is generally known as reactive compounds, a property on which their bioactivities are based. Knotweed is known for its high concentration of emodin: reported levels of emodin in knotweed vary from $15-40 \mathrm{~g} / \mathrm{kg}$ of dry matter in roots, $7-20 \mathrm{~g} / \mathrm{kg}$ in stems and 5$25 \mathrm{~g} / \mathrm{kg}$ in leaves (Rui et al., 2018). High levels of Emodin are also present in Rheum palmatum (Chinese or ornamental rhubarb), a species that is well-known in traditional Chinese medicines, as is Asian knotweed. Emodin is also found in other plants of the knotweed family, including common rhubarb (Rheum rhabarbatum: $\sim 20 \mathrm{mg} / \mathrm{kg}$ dry stem) and various types of sorrel, and in alder buckthorn (Frangula alnus) and various lichens.

Emodin has antimicrobial, antiviral, anti-inflammatory and laxative effects. A similar anthraquinone (1,8-dihydroxy-3-hydroxymethylanthraquinone, or aloe-emodin) is found in the well-known medicinal succulent Aloe vera and is considered the most important bioactive component in that plant. Aloe vera extracts, with aloe-emodin, are used in skin care cosmetics and ointments. In various human cancer cell lines and lab animals, emodin from Asian knotweed or Chinese rhubarb was shown to increase the effectiveness of commonly used cytostatics. Research is now being performed to see whether emodin itself, or chemical derivatives thereof with fewer side effects, could be used in chemotherapy. Emodin, combined with the breast-cancer medication toremifene, was recently proposed by American scientists as part of an experimental therapeutic medicine against Covid-19, as emodin slows down the adhesion of SARS-CoV, the predecessor of Covid-19, to the human receptor protein ACE2 (Zhou et al., 2020).

Like several other anthraquinones, emodin is a natural colourant (Singh et al., 2015). It is used to dye paper, leather, wool, silk, art paints and food. The substance itself is yellow-orange (the characteristic orange colour of the roots, see Figure 5), but once purified, it can be mixed with metals to create specific colours of paint, such as brown (with copper), olive green (iron), red-violet (chrome) or bright yellow (tin). Emodin colours are light- and water resistant.

\subsubsection{Other components:}

Phenolic compounds: in addition to the main compounds resveratrol and emodin (and their derivatives), Asian knotweed contains a large series of other phenolic compounds. Many phenolic compounds have antioxidant effects and are therefore often considered as potentially health-beneficial:

- Flavonoids, like derivatives of quercetin (known from onions and apples) and luteolin (in celery, leek and capsicum). Quercetin derivatives are especially found in the leaf: up to $3 \mathrm{~g} / \mathrm{kg}$ of fresh weight. This is similar to capers, the richest food source of quercetin in Europe, and some 10 times more than in onions. Knotweed roots contain 100 times less quercetin than the leaves.

- Catechins (flavan-3-ols) and their polymers, also known as procyanidins or condensed tannins (known from products like apple, tea and cacao). These are present in the entire plant, with the highest levels in the stems: up to $4 \mathrm{~g} / \mathrm{kg}$ of fresh weight (two times less in the roots). In comparison: fresh tea leaves (tea is considered a healthy beverage mainly due to these catechins) contain nearly $25 \mathrm{~g} / \mathrm{kg}$ of fresh weight.

- Caffeic acid derivatives (as found in coffee and lettuce). 
Polygoacetophenoside, a glucose derivative of acetophenone. Acetophenones are used as industrial solvent, in the preparation of resins, and as aromatics in perfumes. They also have an insecticide-like effect. Whether the specific form of acetophenone in Asian knotweed (namely tetrahydroxyacetophenone) is also suitable for these purposes is not yet known. Polygoacetophenoside is mainly found in the leaves of knotweed at levels up to $7 \mathrm{~g} / \mathrm{kg}$ of fresh weight (50 times less in the roots).

Carotenoids are a group of lipid-soluble plant colourants with antioxidant activities. Together with chlorophyll (green pigment in leaves) they are an essential part of the photosynthesis system of plants. Carotenoids also serve as yellow, orange or red colourant in certain fruits (including tomato and peppers) and flowers (such as chrysanthemum and marigold). Carotenoids, and especially alfa and beta-carotene (orange carrots), are also known as pro-vitamin A, required for the production of retinol in the eyes. Carotenoids in knotweed are only found in the leaves, in which lutein is the main carotenoid at $25-140 \mathrm{mg} / \mathrm{kg}$ of fresh weight (similar to spinach: $20-125 \mathrm{mg} / \mathrm{kg}$ ), followed by betacarotene at $60-100 \mathrm{mg} / \mathrm{kg}$ (spinach $10-100 \mathrm{mg} / \mathrm{kg}$; carrots $10-50 \mathrm{mg} / \mathrm{kg}$ ). The total of carotenoids in green knotweed leaves is approximately $350 \mathrm{mg} / \mathrm{kg}$ of fresh weight, in yellow (autumn) leaves it is three times less (Metlicar et al., 2019).

Like all other plants, knotweed probably contains hundreds or even thousands more compounds of which most are still unknown or have yet to be further studied. It is still unclear which of these compounds, aside from the ones indicated above, demonstrate bioactivity and could thus be important for the pharmaceutical/medicinal effect of knotweed extracts.

\subsubsection{Human nutrition and supplements}

In Asian countries, knotweed is also used in cooking. Thanks to their mild acidic flavour, young shoots are eaten like asparagus or used as a replacement for rhubarb. It is also said to be a good source of vitamin A (carotene), vitamin C (ascorbic acid), minerals and phenolic antioxidants such as resveratrol (see 5.1.2). The fact that the young shoots are eaten in Asian countries does not automatically mean that they would be allowed for human consumption in the EU.

The European Food and Safety Authority (EFSA) has determined that food that had not been consumed on the continent to a significant degree before 15 May 1997 is considered a 'novel food' and cannot be marketed before the EFSA grants authorisation. This is only granted after a novel food dossier is submitted to EFSA, containing as much scientific and technical evidence as possible that the new food can be produced and consumed in a safe way, that it does not contain any toxic components, allergens and contaminants, and that it has no harmful effect on people who consume it. This all demands detailed and costly research, and processing the dossier after submission takes at least 1.5 years. The chance that Asian knotweed can be used for human consumption is therefore small (in the short term, at least) and demands significant investments. Moreover, the application market is especially small because the 'cultivation' does not take place under controlled and hygienic conditions. The EFSA requires the description in the novel food dossier of the cultivation of the new crop and a prove that the bacterial level is low enough for consumption.

The application of compounds from Asian knotweed as drugs in the short term is also very unlikely as authorisation of a drug including all human intervention studies are even more costly and would take even longer. Moreover, here too, a controlled, hygienic and constant 'cultivation' is essential, which is not in line with the presence of the pest plant on embankments and along the tracks.

The use of plants and plant materials for the supplement market is less regulated but, here too, compliance with the regulations of the Commodities Act Decree 'Herbal preparations' (Directive $2002 / 46 /$ EC) is required. Again, the issue is that the 'cultivation' of Asian knotweed is not controlled and is realised under non-hygienic conditions. 


\subsubsection{Animal feed}

Leaves and young stems of knotweed could be used as animal feed for sheep and pigs. Farmers are only allowed to use this if the knotweed grew on their own land, however. In view of the health of the animals, the diet cannot consist solely of knotweed. For the use of commercial animal feed and/or bedding, the material may not contain any litter or harmful herbs (such as tansy ragwort).

Unfortunately, the transport of fresh plant material carries a major risk of further spread. Stem fragments that land on the ground elsewhere can grow to become new plants. If it would be added to animal feed on a large scale and marketed as a commercial product, the condition of the controlled and hygienic 'cultivation' of Asian knotweed again applies. Knotweed growing along roads and tracks does not meet this requirement.

\subsection{Raw materials}

The processing and valorisation of biomass is in full development. Where possible, the specific applications of biomass from Asian knotweed are included. As the biomass of knotweed involves a relatively small sub-stream in the green refuse stream involved in management along the tracks, the developments in the field of processing cuttings from the sides of roads or tracks or green refuse from water management have also been included. We list various examples of methods to process and market the green refuse in a (more) high-quality way.

\subsubsection{Biorefinery}

One of the possible solutions is to valorise green refuse after removal via so-called biorefinery techniques. This allows biomass to serve as a raw material for the production of protein (technical applications), fibres (various application), as a source of specific components and minerals (specific manure substrate) and energy. The biorefinery examples below involve the processing of cuttings from along roads or tracks or green refuse from water management (Van Lieshout et al., 2019; Biomassa Alliantie, 2017). There are no specific examples of biorefinery with refuse from Asian knotweed. These initiatives may offer leads for the processing of knotweed refuse, possibly combined with other green refuse resulting from track management.

\section{Protein}

The company Grassa! is developing a technology and equipment that extracts substances like protein, fibres and minerals from green refuse which is then used to make animal feed and protein supplements for concentrated feed. The protein is separated from the fibres and made suitable as a raw material for animal feed. This protein cannot be used for human consumption before a novel food dossier has been submitted and approved (see 5.1.4). The dossier would have to be specifically focused on the extraction of protein from this plant and the safety aspects of the isolated protein. Besides protein, the cuttings are also used to extract fibres, sugar, minerals and phosphates that can be used as soil improver. Not all cuttings can be used directly with this processing technique. Harvestagg developed a technology in which the sap from the cuttings is processed into protein and carbohydrate-rich animal feed. The fire-rich residual stream that results from this process is fermented into biogas for generating energy.

\section{Lignocellulose}

Indugras is currently working with TNO to develop an integration technology in which biomass is heated with super-heated steam to retrieve lignocellulose from cuttings to release useable components such as cellulose, hemicellulose and lignin. These components can be used as energy-rich animal feed applications. The technology is currently only being used on a laboratory scale and not commercially available. 


\section{Sap}

In addition to phosphate, sugar and minerals, the sap from cuttings can also be used to extract salt. Grassa! and NewFoss are extracting fibre, protein and sap from cuttings. Grass2grit has developed a technology that separates the salt from the sap, which is then used as a biobased de-icing product on roads. The biobased salt is mixed with solid salt (ratio: $20 \% / 80 \%$ ) which gives it a similar effect as existing road salt.

\section{Fermentation/bio-ethanol}

The fermenting of cuttings can help produce bio-ethanol in which sugars are converted into ethanol. At this time, fermentation is mainly used on sugar-containing crops like cane and beet or starchcontaining crops like maize and wheat. Cuttings commonly contain a high level of cellulose which makes the conversion process more difficult and requires a pre-process to unlock the cellulose in fermentable sugars. There are various technologies in development to achieve this, such as enzymatic hydrolysis (ECN) and the super-heated steam process (Indugras).

\section{Fibres}

There are no known specific applications of Asian knotweed related to the (re)use of fibres other than for energy recovery via fermentation and incineration (see 5.2.4 and 5.2.5). Generally, fibres released in green refuse stream extraction processes such as roadside grass and elephant grass (Miscanthus) can serve as raw material for various purposes, including paper, bio-composite and building materials (see text box below). Biobased materials are an attractive alternative to conventional construction materials insofar as the mechanical strength is sufficiently strong.

Bamboo is an example of a biobased construction material. In many Asian countries, natural bamboo is used to build houses, scaffolding and the like. Research by Chen et al. (2020) shows that the mechanical properties of bamboo can be improved by pre-processing to increase its range of applications. The pre-processing consists of two stages - a shared delignification followed by microwave heating. Delignification makes the cell walls of bamboo softer, resulting in a better compaction during the heat treatment. The benefit of heating with microwaves is that the material is heated quickly and homogenously and that the water in the bamboo is driven out without affecting its structure. The artificially aged bamboo has better mechanical properties than the original natural bamboo. The specific tensile strength of the modified bamboo is $560 \mathrm{MPa} \mathrm{cm} \mathrm{g}^{-1}$ at a relatively low density of $1.0 \mathrm{~g} \mathrm{~cm}^{-3}$. These properties make the material suitable for lightweight technical applications. 
Below are examples of Dutch initiatives that use fibres from green refuse streams (mostly roadside cuttings and Miscanthus) as a raw material for various products (Van Lieshout et al., 2019; Biomassa Alliantie, 2017)

\section{NewFoss}

Newfoss uses microbiological processes to refine cuttings and extract proteins, acids and salts. This results in lignocellulose that can be used as raw material for the paper industry (Figure 6). The salts can be used as a plant-based artificial fertiliser replacement or as road salt. The valorisation of the acids is still being studied and the watery component is supplied to a fermentation plant. Newfoss recently opened its first commercial plant, processing some 40,000 tonnes of biomass a year into paper and cardboard (Van Berm tot Bladzijde pilot; BeeGreen grass egg container). NewFoss supplies lignocellulose fibres as raw material to replace glass and stone wool in insulation applications, as a replacement for peat in casing material for mushroom farming, in potting soil and other cultivation mediums, and as a sustainable alternative to wood-based raw material in paper and cardboard (https://newfoss.com).

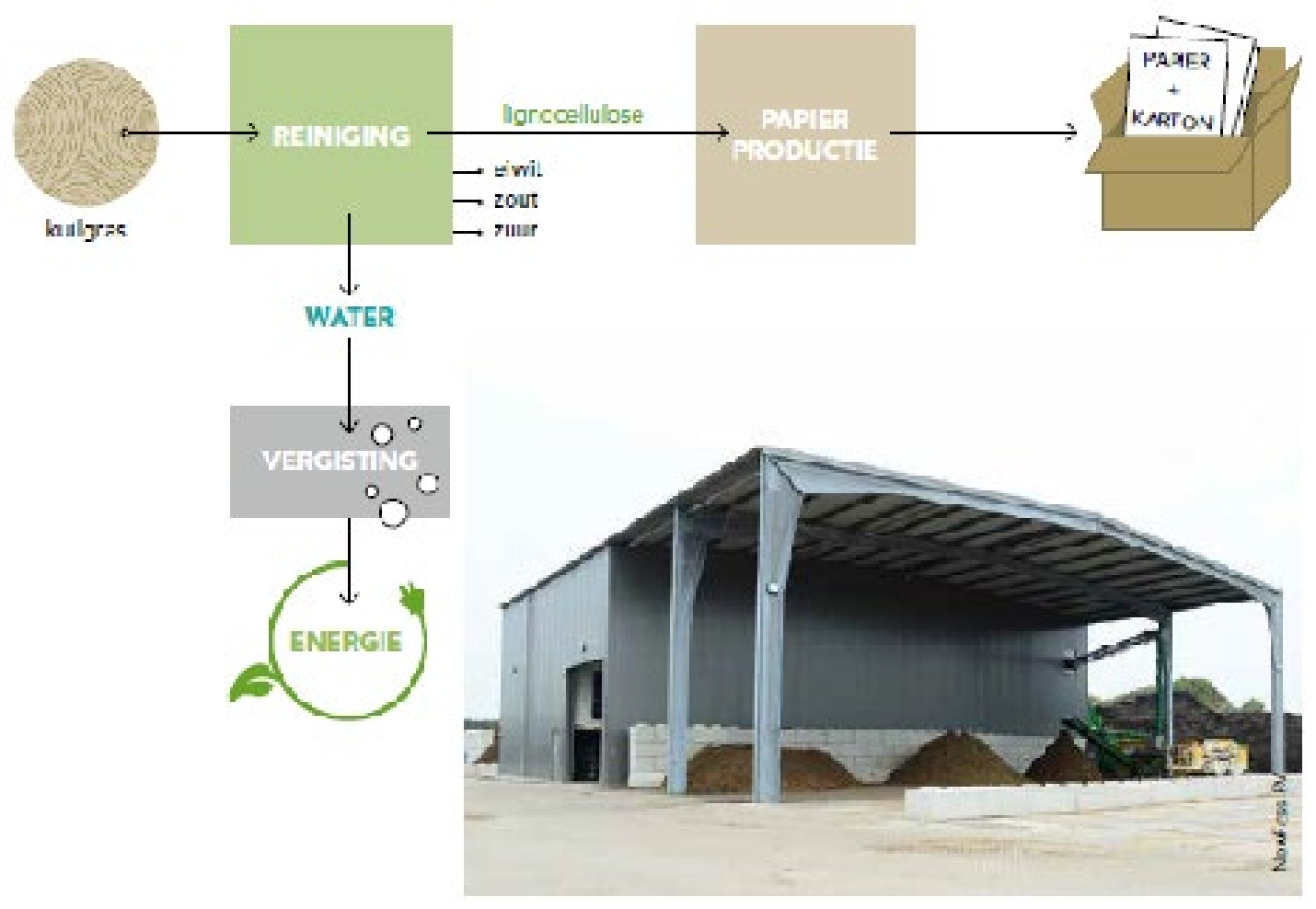

Figure 6 Schematic overview of the processing of grass to paper and energy (Photo: NewFoss BV).

\section{Grassbloxxx}

Rijkswaterstaat, the Port of Amsterdam, Province of North Holland, Zuiderzeeland district water board and NewFoss started a consortium in April 2018 to realise a biomass chain based on regionally available cuttings. The goal is to convert 50,000 tonnes and eventually as much as 100,000 tonnes of grass and other biomass a year into insulation panels and other fibre products (Vegetation2grit).

\section{Millvision and NPSP}

In addition to paper, fibres can also be used to make composite. The natural fibre is mixed with a binding agent, after which it is pressed with organic resin into bio-composite that can be used in construction materials (tree supports, shoring material) and simple garden furniture. Millvision is working on a roadmap to process cuttings from three border regions (Biesbosch-Altena, Dommeldal and Vallei van de Zwarte Beek, and De Zoom-Kalmhoutse Heide) into regional products. Rijkswaterstaat is working with Millvision on experiments with applications of roadside cuttings such as the crash barrier in Zeeland and biobased benches to increase the sustainability of streets. NPSP is already producing various composite products strengthened with natural fibres under the label Nabasco ${ }^{\circledR}$ which are suitable for indoor and outdoor applications (http://www.npsp.nl/index.asp). 


\section{Biobound}

Biobound is using cuttings from Miscanthus (elephant grass) to process in construction materials such as street furniture, park siding, tiles, stairs and reinforcement plates for walking or biking trails

(Figure 7). The concrete products are made from recycled concrete rubble granulate (from sand to grit fraction) and contain half a $\mathrm{m}^{3}$ of bulk miscanthus per $\mathrm{m}^{3}$ concrete. The Miscanthus comes from the direct surroundings of Schiphol airport and was initially intended to repel geese from the runways (https://biobound. $\mathrm{nl} /$ ).

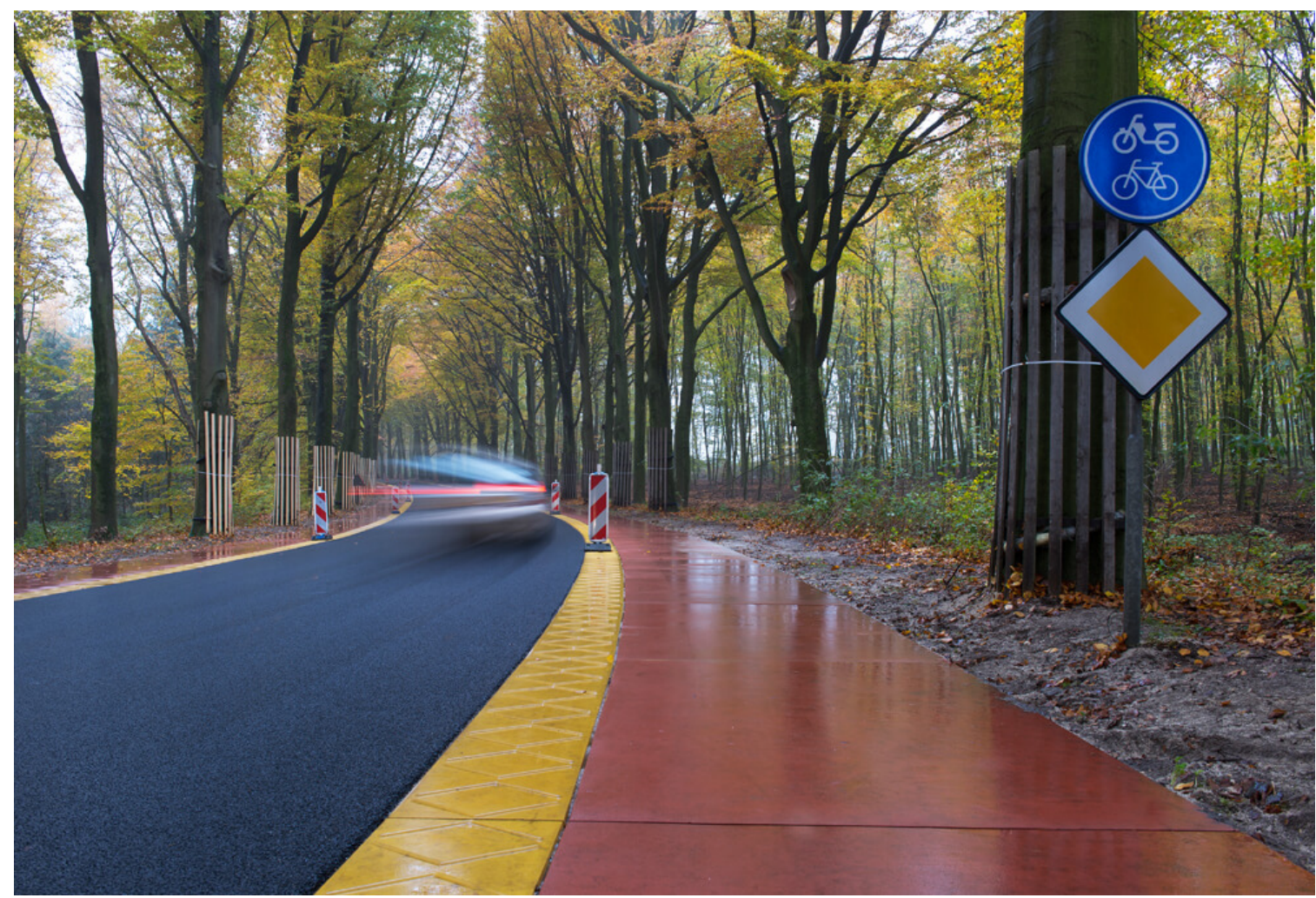

Figure $7 \quad$ Processing of elephant grass (Miscanthus) in reinforcement plates for bicycle paths (Photo: Biobound).

\section{NTP-groep}

NTP-groep has developed a technology in which asphalt is produced from Miscanthus (elephant grass). The bitumen is replaced by the bio-based binding agent lignin which comes from the elephant grass. The product is produced under the name 'Grasfalt', but is still under development. Currently $50 \%$ of the bitumen is being replaced by lignin (https://www.ntp.nl/).

\section{Grasgoed}

Composting has always been a high cost items for organisations like Natuurmonumenten (the Dutch society for the preservation of nature) which removes thousands of tonnes of cuttings from its nature reserves every year. The Interreg project GrasGoed focuses on converting cuttings into sustainable insulation mats. Natuurmonumenten is currently experimenting with the use of the mats in its offices in Hedel.

\section{Pilots for furniture, road salt and animal feed}

Several municipalities in the province of Drenthe are working with research institutes and companies to see how roadside cuttings can be used for the production of office furniture and cardboard. TU Delft, the province of North Holland and regional businesses are currently studying whether roadside cuttings can be used to make road salt. The province of North Brabant is having its cuttings processed right away; it is bruised and ground (grass refinery), and the sap is used as a raw material for animal feed, while the fibres are used as a raw material for the production of cardboard. 


\subsubsection{Composting}

With regard to biomass processing, green refuse is currently mainly used as a raw material for composting. Composting results in a stable organic material that can be used as soil improver (not fertiliser). Adding compost or organic material prevents the depletion and structural deterioration of the soil. Although the nutrients from green refuse become available again for the soil life and for absorption by plants, the energy is not utilised. Compared to fresh material, compost contains a high percentage of stable organic matter that is still present in the soil after a year. In contrast to straw, reed and branches, grass cuttings are less suitable for composting due to the presence of large amounts of lignin and cellulose. In practice, cuttings are mixed with other green refuse streams to ensure the composting process goes well and a good-quality organic matter is obtained.

Compost is hygienised, which means that plant pathogens and weed seeds have been eliminated. Compost tests show that vital plant parts, such as leaves, stems, rootstocks and seeds of invasive exotic species like Asian knotweed, Himalayan balsam and giant hogweed, can be eliminated in a controlled composting process (BVOR, 2017; Fuchs, 2017; MacFarlane, 2011). For Japanese knotweed the temperature of all the plant material must be at least $50^{\circ} \mathrm{C}$ for a period of 72 hours to be effective (Xian et al., 2011). Practical tests by composting companies show similar results. Residual streams of Asian knotweeds can thus be composted without risk and applied as soil improver if the required processing conditions during the composting are met. To secure the process conditions, composting companies can be certified as a 'recognised processer of invasive exotic species' (www.bvor.nl).

\subsubsection{Bokashi}

Bokashi is a product that can be made from nearly every organic material. The organic residue is well divided into layers to which clay minerals, seashell lime and micro-organisms are added. The matter is then covered air-tight (like silage) and fermented in a low-oxygen environment for 8 to 10 weeks. The organic material is preserved in the Bokashi pit and only starts breaking down when it is spread over the land and comes into contact with oxygen. On land, the stored carbon is released as $\mathrm{CO}_{2}$ so does not contribute to combatting climate change. With regard to the soil quality in the long term, the humus in particular is bound to the soil for years. The percentage of humus in compost is larger than in Bokashi (BVOR, 2017).

At this time, there are uncertainties about the added value and risks of Bokashi. It has yet to be proven that weed seeds and plant pathogens are effectively eliminated in Bokashi. This also applies to the refuse of invasive plant species such as Asian knotweed. In 2019, the municipality of Amersfoort carried out several practical tests to find out whether knotweed survives the process. The tests were performed in accordance with the method of the company Bij de Oorsprong. The results showed that the knotweed was no longer germinable after it had been through bokashi (Tijhuis, pers com.). It is not known which bandwidth for the process conditions would be sufficient to stop knotweed from spreading. Bokashi therefore does not guarantee that the seeds and other plant parts from which the invasive variety can multiply are eliminated.

Bokashi is not authorised as a soil improver at this time so cannot be sold and used as such (it is not included in Annex Aa of the Manure and Fertilisers Act so is not a recognised fertiliser). Bokashi produced on one's own grounds with one's own organic material can be used as soil improver (BVOR Factsheet Bokashi).

\subsubsection{Fermentation (biofuel)}

Fermentation of biomass streams is applied on a large scale in the Netherlands. In fermentation, biomass is converted into energy and fertiliser (digestate) via a controlled organic process. The most commonly used type is wet fermentation. Common green household waste fermentation plants and co-fermentation plants can process green refuse streams such as (roadside) cuttings in a limited way - up to approx. $10 \%$ of the total input. Mechanical pre-processing of the cuttings (to shrink and unlock) is required. Green refuse streams of 'uncontrolled cultivation' may contain pollutants such as sand and litter which can cause damage to the fermentation plant (damage to pumps and mixing 
systems, formation of sludge and surface layers). There are currently a number of fermentation plants that can process large amounts of cuttings on a commercial scale. Asian knotweed is considered a potential energy source due to its high photosynthesis efficiency, strong growth, suitability for growth on marginal soils and the absence of pathogens and pests. A yield of 15 tonnes ha-1 of dry matter achieves a methane production of $3800 \mathrm{~m}^{3} \mathrm{CH}_{4}$ ha-1, which is almost similar to some 47,000 car kilometres ha-1 (Strašil \& Kára, 2010; Lehtomäki et al., 2008). Combined with other green refuse streams in order to increase the total volume, the fermentation of knotweed could be an option for biogas production.

Green household waste fermentation plants and co-fermentation plants are technically and financially able to partly co-process cuttings (especially grass species) (Brinkman, 2014). A condition is that the current cutting around the tracks, primarily focused on cost-efficient logistics, is reorganised. Fermentation requires the chain to be set up for a more continuous production of good-quality substrate, which then pays off via the biogas production generated during the fermenting process. The costs of obtaining knotweed as a good-quality substrate would be higher than for common management, however.

In addition to wet fermentation, dry fermentation can also produce renewable energy. This processing method is hardly used, but could eventually be the key to an optimal processing of cutting fermentation. Dry fermentation is ideal for the fermentation of green household waste combined with cuttings. Moreover, green household waste fermenters come with a standard and extensive preprocessing, which means sand and litter are no longer an issue. Dry fermentation of cuttings could result in savings compared to natural gas consumption on the greenhouse gas emissions. The gross savings would be around 150 tonnes per 1000 tonnes of cuttings, while the net savings are around 60 tonnes (Zwart \& De Boer, 2015). The province of Utrecht started a practical test in 2019 with Rijkswaterstaat, De Stichtse Rijnlanden water board and Attero.

Digestate is a side product of biomass fermentation. In case of the (co-)fermentation of fertiliser, the majority of the minerals (NPK) ends up in the digestate. Digestate classified as animal manure can be used for agricultural applications. This would increase the total amount of animal manure. An alternative in development is upgrading digestate into products with a higher added value such as mineral concentrate, or vegetable compost in case of a green household waste fermenter. Fermentation without the upgrading of digestate is a proven technology; the upgrading of digestate is still being developed (BVOR, 2017).

\subsubsection{Torrefaction, pyrolysis, incineration and gasification}

Torrefaction, pyrolysis, incineration and gasification are thermal processes in which biomass is converted into energy, biofuel and/or other products. Conventional plants mainly operate on woody biomass. Various studies show that Asian knotweed is a crop with a high energy potential (Brunerova et al., 2017; Strašil \& Kára, 2010).

Knotweed biomass has a relatively high energy value $\left(18,402 \mathrm{MJ} \mathrm{kg}^{-1} \mathrm{DM}\right.$ for plant parts above ground) and a low ash content. The energy value depends on the moisture content (time of harvesting); at $25 \%$ moisture, the energy value is $14,563 \mathrm{MJ} \mathrm{kg}^{-1}$, but at $60 \%$ moisture it's just $7,809 \mathrm{MJ} \mathrm{kg}{ }^{-1}$. The average ash content in the plant varied from $3.12-4.6 \%$, depending on the origins. A low ash content has a favourable effect on the emissions released during incineration. Asian knotweeds supply a stable and relatively high amount of biomass with an energy value similar to dry wood chips or wood pellets (Strašil \& Kára, 2010). Knotweed biomass can be used to produce fuel pellets that meet the chemical and mechanical standards for pellet production (moisture content $8.84 \%$, ash content $1.14 \%$, gross caloric value $19.43 \mathrm{MJ} \mathrm{kg}^{-1}$, net caloric value $17.71 \mathrm{MJ} \mathrm{kg}^{-1}$ ). For a biomass yield of approx. $30 \mathrm{t} \mathrm{ha}^{-1}$ of dry matter, this comes down to $583.32 \mathrm{GJ} \mathrm{ha}^{-1}$ (Brunerova et al., 2017). 


\subsection{Other applications}

\subsubsection{Phytoremediation}

Phytoremediation is a technology in which plants are used to immobilise or remove pollution in the soil. The most common form of phytoremediation is a technique in which plants absorb toxic heavy metals from polluted soils and accumulate them in their tissue. Harvesting and removing the plants that contain the pollution will reduce soil pollution (Jan \& Parray, 2016). A benefit is that the organic and physical structure of the soil is preserved (Baker \& McGrath 1994). Phytoremediation is a relatively cheap and sustainable process but it can take years before pollution has been reduced to an acceptable level.

Knotweed appears to accumulate more heavy metals than other plant species and is a 'hyperaccumulator' for Zn and Cd. Knotweed has therefore been designated as a suitable variety for phytoremediation of soils polluted with Zn and Cd (Hulina and Đumija, 1999). Research in Japan showed that knotweed growing on polluted soils can accumulate heavy metals such as copper (Cu), zinc ( $\mathrm{Zn}$ ) and cadmium ( $\mathrm{Cd}$ ). The metals mainly accumulate in the cell walls of the rootstocks and leaves (Hulina and Đumija, 1999). In plants originating from non-polluted soils, the $\mathrm{Cu}, \mathrm{Zn}$ and $\mathrm{Cd}$ levels were found to be 20,110 and $2 \mathrm{mg} \mathrm{kg}^{-1} \mathrm{DM}$, respectively. For plants originating from soils polluted with heavy metals ( $\mathrm{Cu}: 3,000 \mathrm{mg} \mathrm{kg}^{-1} \mathrm{DM}, \mathrm{Zn}: 10,000 \mathrm{mg} \mathrm{kg}^{-1}$ and $\mathrm{Cd}: 100 \mathrm{mg} \mathrm{kg}^{-1}$ ), the levels were 2,300, 6,700 and $62 \mathrm{mg} \mathrm{kg}^{-1} \mathrm{DM}$, respectively (Rahmonov et al., 2014). Research in the Czech Republic showed similar results, with high levels of $\mathrm{Cu}, \mathrm{Zn}, \mathrm{Pb}$ and $\mathrm{Cd}$ in the leaves. These properties make it difficult or impossible to use Asian knotweed for human nutrition or animal feed that grows in the wild and accumulates undesirable components from the soil.

\subsubsection{Honey production}

Asian knotweed blooms with creamy-white flowers from August to late September. The flowers are very popular among bees looking for nectar, serving as an attractive source relatively late in the season as most other plants have started wilting. The honey that bees produce with the knotweed nectar is a mild version of buckwheat honey, dark in colour and seemingly dark red when held up against the light. The honey appears to be a good source of minerals, especially $\mathrm{K}$ and $\mathrm{Na}$, at levels of 1187-6196 mg kg $\mathrm{mg}^{-1}$ and 58.8-68.8 $\mathrm{mg} \mathrm{kg}^{-1}$, respectively. In addition, the honey contains high levels of calcium (Bobis et al., 2019).

\subsubsection{Design objects}

Designer and developer Amy Vorsselmans makes vases and lamps from plant-based biobased plastic and fibres from agricultural residual streams or originating from herbs, including Japanese knotweed (AIYMES). 


\section{$6 \quad$ Volume streams}

\section{$6.1 \quad$ Biomass}

To make an estimation of the options for upgrading and marketing green refuse streams such as Asian knotweed, it is important to have insight into the acreages and the amount of biomass per surface unit of plant parts both below and above ground.

Biomass measurements of fully closed stands in the Czech Republic show that when harvesting in autumn, when hardly any leaves are left (just stems), F. x bohemica achieves average amounts of 13.2 to 21.4 tonnes of dry matter per hectare. For $F$. japonica the amount of biomass was around 9 tonne ha-1 DM (Strašil \& Kára, 2010). Similar measurements in Slovakia showed biomass yields of approximately 21 tonne ha-1 for $F$. japonica, at a density of 12 shoots $\mathrm{m}^{-2}$. For $\mathrm{F} . \times$ bohemica the yield was around 24.2 tonne ha-1 DM (Eliáš, 1998).

A determination of the biomass of $F$. japonica stands in the UK, where both the above ground and below ground biomass was determined in autumn, showed an average yield of 9.4 tonne ha-1 for the parts above ground and 14.7 tonne ha-1 for the rootstocks to a depth of $25 \mathrm{~cm}$ (Brock, 1994).

Table 1 Biomass (tonnes ha-1 of dry matter) of parts of Asian knotweed above and below ground compared to potato biomass.

\begin{tabular}{|c|c|c|c|c|}
\hline \multirow[t]{2}{*}{ Variety } & \multicolumn{4}{|c|}{ Biomass (tonnes ha-1 of dry matter) } \\
\hline & $\begin{array}{c}\text { Stems and } \\
\text { leaves }\end{array}$ & $\begin{array}{c}\text { Stems } \\
\text { (autumn) }\end{array}$ & Rootstocks & Reference \\
\hline \multirow{2}{*}{ F. japonica } & 21 & & & Eliáš, 1998 \\
\hline & 9.4 & & 14.7 & Brock, 1994 \\
\hline F. bohemica & 24.2 & & & Eliáš, 1998 \\
\hline Potato* & 5 & 0 & 15 & Van Oort (pers. med.) \\
\hline
\end{tabular}

* leaves and stems die after the peak in summer, potato is a tuber

Due to the falling leaves and young shoots, the biomass declines in winter by approx. $42 \%$ for F. japonica and $34.5 \%$ for $F$. $\times$ bohemica. The moisture content of the harvested material also varies throughout the seasons. In autumn, the average moisture content in $F$. japonica was approx. 68\%, while in spring it was just $24 \%$. For F. $\times$ bohemica it was $67 \%$ and $23 \%$, respectively. Harvesting knotweed stands for energy generation should ideally take place after winter (February-March) as it would render pre-drying the material unnecessary due to the low moisture content (Strašil \& Kára, 2010).

\subsection{Asian knotweed along the tracks}

The total acreage of knotweed stands along the tracks is still being studied by combining various data sources. Management data and reports from ProRail show that the growth locations are generally 20-25 $\mathrm{m}^{2}$ but that there are also stands of several hundreds to thousands square metres. For the total number of the 260 reported growth locations and associated surface areas, the average is $400 \mathrm{~m}^{2}$ per growth location - taking into account a significant margin of error. This would mean that the total acreage of the reported stands is approximately $100,000 \mathrm{~m}^{2}$ (10 ha). To what extent the number of 
reported growth locations give an accurate insight into the actual number of stands along the tracks and the associated surface areas is unknown.

Based on a translation of biomass production data from literature (Table 1) and the estimated acreage of the stands (10 ha), the total amount of biomass above ground (stems and leaves) for Japanese knotweed ( $F$. japonica) is, globally, between 94 and 210 tonnes DM. For Bohemian knotweed ( $F$. $x$ bohemica) the amounts are between 132 and 242 tonnes DM. These figures can be 'harvested' annually on the condition that management and control measures are stopped, as that would lead to a structural reduction of the biomass. The total amount of underground biomass (rootstocks) can be estimated based on literature at a one-off 147 tonnes DM.

Generally, Asian knotweed is a common and well-assimilated variety in Europe, except in the most southerly countries. It does not just involve areas around the European rail network, but also other locations - in urban environments, along roads and in nature reserves. There are no accurate acreage data on knotweed stands, but at the European level it involves a substantial but very scattered acreage of Asian knotweed.

\subsection{Common management methods around the tracks}

Management of the land along the tracks and thus the management of knotweed is an integral part of the PGO systematics. This means that ProRail applies performance requirements to the activities and demands results from the contractors which they must achieve under statutory and contract regulations. The way in which invasive exotic species like knotweed must be dealt with has yet to be detailed in most performance contracts. Contractors must take measures to prevent invasive exotic species from being introduced or spread further during their activities. This involves measures such as visual inspections for the presence of invasive exotic species before starting the activities, reporting stands and marking them clearly, and staying alert during the processing and transport of soil. Within the set frameworks, contractors can determine how they perform their activities. As a result, the detailed information on the applied management methods under contract and the associated costs is not available.

The most common management methods for Asian knotweed along the tracks are:

- In all activities for green maintenance, the costs for the required safety measures must be taken into account.

- Cutting without removal, with the knotweed stands included in the regular cutting. This method sees the plant parts above ground cut down to small segments. The technique is therefore unsuitable if the biomass were to be used for other purposes.

- Individual cutting and removal: the knotweed stands are cut in an individual process and the cuttings are collected and removed to a recognised processor (generally dumping, no biomass reuse). Individual cutting and removal is in line with the process if the biomass were to be used for other purposes.

- Thermal by means of hot water: the knotweed stands are treated (sprayed) with hot water various times per season. The plant parts above ground are blanched, as it were. As a result, this technique is unsuitable if the biomass were to be used for other purposes.

- Thermal by means of electricity: the knotweed stands are burned just above ground level several times per season. To protect employees from shocks due to falling stems, they are topped just before the process to approx. $50-60 \mathrm{~cm}$ above ground. If the plant parts above ground were to be collected, the technique is suitable if the biomass were to be used for other purposes.

Cutting without removal and hot water are not suitable methods if the biomass above ground were to be used for other purposes. Individual cutting and removal with a cutting-suction combination is the best option and relatively cheap. The accessibility of the stands does play an important role herein. While electricity is also suitable in principle it is complex and therefore expensive, and the risks to items like cables and pipelines around the tracks must still be mapped. Digging up the rootstocks is an effective remediation method but carries a risk of the knotweed spreading and is costly (Table 2 ). 
Table 2 General estimation of the costs for management of 10 ha knotweed stands with various methods based on expert judgement.

\begin{tabular}{|c|c|c|c|c|c|}
\hline & $\begin{array}{l}\text { Cutting without } \\
\text { removal }\end{array}$ & $\begin{array}{l}\text { Individual } \\
\text { cutting and } \\
\text { removal } \\
\text { (cutting-suction } \\
\text { combo) }\end{array}$ & Hot water & Electricity & Digging \\
\hline Frequency per year & 1 & 1 & 5 or 6 & 4 or 5 & One-off \\
\hline Management & $€ 9,000$ & $€ 11,000$ & $€ 190,000$ & $€ 800,000$ & \\
\hline $\begin{array}{l}\text { Transport and dumping } \\
\text { ( } 450 \text { tonnes fresh) }\end{array}$ & $\mathrm{n} / \mathrm{a}$ & $€ 20,000$ & $\mathrm{n} / \mathrm{a}$ & $\mathrm{n} / \mathrm{a}$ & \\
\hline Digging and sifting & & & & & $\approx 20 \mathrm{M} €$ \\
\hline Total & $€ 21,000$ & $€ 43,000$ & $€ 202,000$ & $€ 812,000$ & $\approx 20 \mathrm{M} €$ \\
\hline
\end{tabular}

'Harvesting' rootstocks requires digging up the stands and sifting out the rootstocks. Digging and sifting carries significant risks of further spreading the knotweed due to the movement of rootstock fragments with the soil or via the material. For digging out stands, it is recommended to consider the knotweed as a soil pollutant and removing it under remediation conditions. This makes the task very elaborate with regard to additional measures, and demands a high level of experience from the contractor. The main disadvantages of large-scale digging are that a lot of ground with a low infection risk is also removed, and that the soil then leaves the soil chain, which is not very circular or sustainable and organisationally complex due to the required licenses, reports, transport administration and the like.

Digging, sifting and processing the soil on site has the benefit that no interim storage is required and the work can be performed relatively quickly. The disadvantage is that there is no control of any remaining plant parts in the pit bottom or walls, so fragments of rootstocks could be left behind in the sifted and returned soil. After-care is recommended. This involves monitoring the locations for one or two seasons and (manually) digging out any upcoming plants.

Digging and sifting on site is realised with drum or flat sieves with a sifting fraction of $1-2 \mathrm{~cm}$ (Figure 8). This ensures that all large segments of rootstock are removed from the soil. The sifted-out rootstocks can then be removed for processing. Sifting mainly works well on sandy soils. In addition, there are special buckets with rotating 'fingers' available that can be attached to a mobile crane. The rotating parts allow the soil to fall through the bucket, while the larger parts $(>2 \mathrm{~cm})$ remain inside (Figure 9). This type of machine is suitable for sifting Asian knotweed rootstocks. The sifting of knotweed-infected soil results in a substantial decline of regrowth (number of shoots) compared to untreated soil, but vital rootstock fragments will remain. 


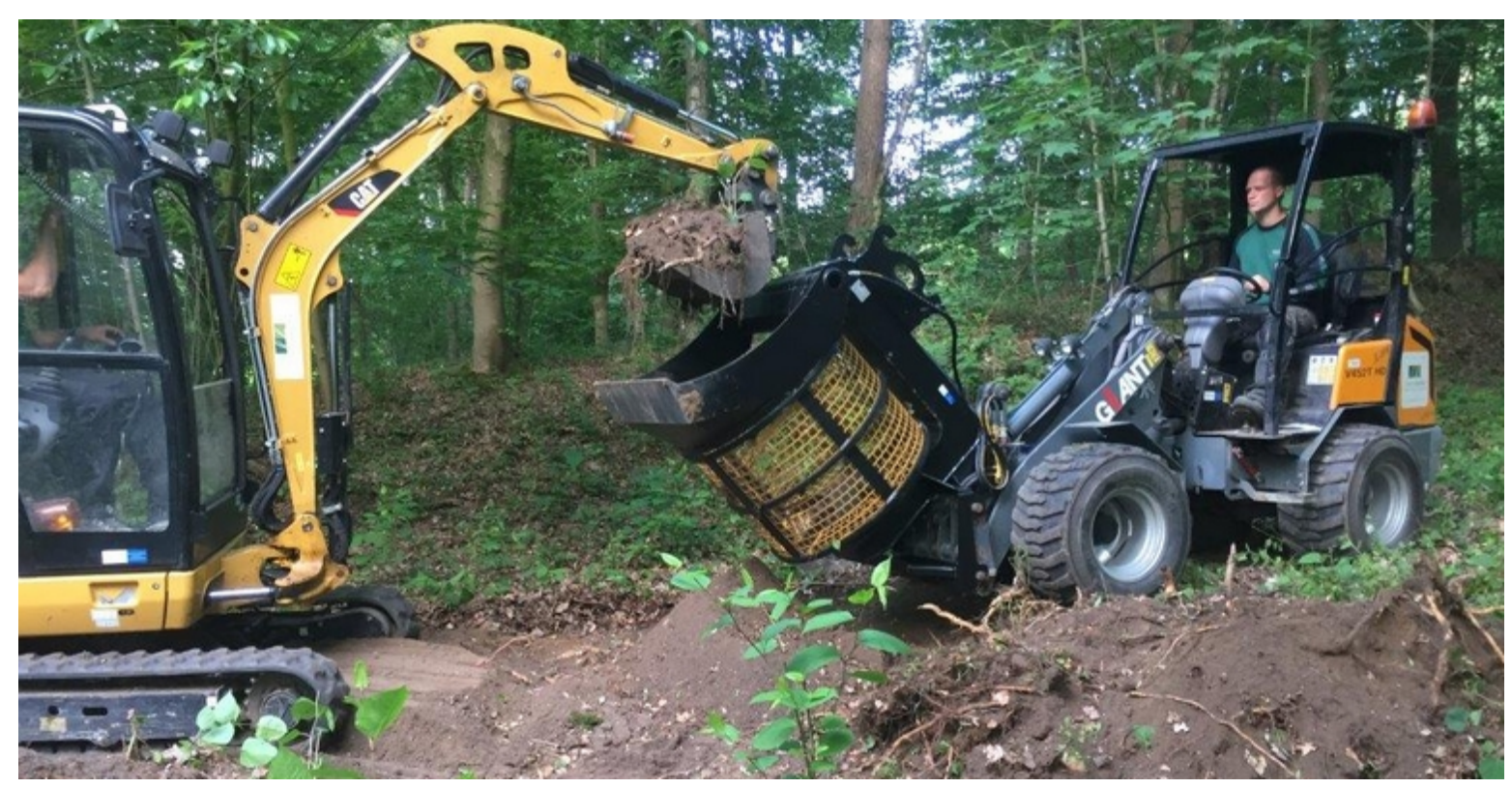

Figure $8 \quad$ Machine digging and sifting (drum sieve) of Asian knotweed rootstocks.
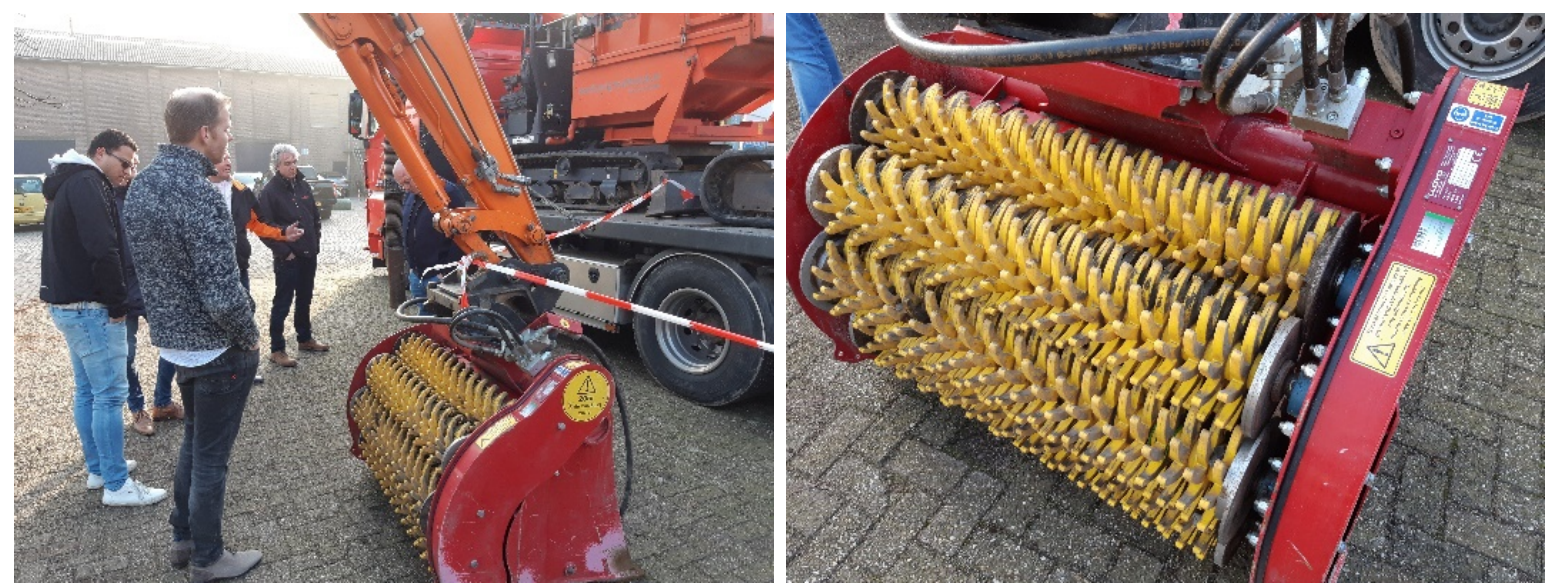

Figure 9 Mobile crane with bucket and rotating 'fingers' for digging and sifting. The soil falls through the bucket while larger segments $(>2 \mathrm{~cm}$ ) remain inside. 


\section{$7 \quad$ Evaluation}

Existing applications and uses of Asian knotweed, especially in Asia, are placed in the perspective of European legislation and regulations. Developments in the field of biomass upgrading in general are described item by item. This includes biorefinery, upgrading to soil improver, energy recovery and phytoremediation. Finally, we indicate how the options to upgrade knotweed biomass fit into ProRail's management goals.

\section{Components}

- Asian knotweed is a traditional (folklore) medicine in countries such as China, Korea, Taiwan and Japan.

- Both the knotweed rootstocks and parts above ground contain a variety of plant-specific compounds, or phytochemicals. Medicinal extracts are obtained by extracting the phytochemicals from the dried and finely ground plant parts from above or below ground and adding hot water ('herbal tea') or an alcoholic solution ('tincture').

- Asian knotweed contains relatively high concentrations of phenolic compounds such as resveratrol and emodin, which are said to have health-promoting effects. A good scientific substantiation of these effects in humans is not available, however. The exact amounts of these components depend on growth conditions, development stage and the way in which the chemical analyses are performed.

- Plants that grow in the wild in an uncontrolled way and were not eaten on a large scale before 1997 cannot be commercially marketed as an ingredient or food product under EU regulations. The rules are even stricter for medicinal use.

- Emodin is a natural colourant that is used to dye paper, leather, wool, silk and art paints.

\section{Human nutrition}

- In Asian countries, knotweed is also used in cooking. Due to their mild acidic flavour, young shoots are eaten like asparagus or used as a replacement for rhubarb. It is also said to be a good source of vitamin A (carotene), vitamin C (ascorbic acid), minerals and phenolic antioxidants such as resveratrol.

- In the EU, food that was not consumed in Europe to a significant degree before 15 May 1997 is considered 'novel food' and cannot be marketed without EFSA authorisation. This is only granted after a novel food dossier is submitted to EFSA, containing as much scientific and technical evidence as possible that the new food can be produced and consumed in a safe way, and that it does not contain any toxic components, anti-nutritional factors, allergens and contaminants. In addition, cultivation must take place under controlled and hygienic conditions. Asian knotweed that grows along tracks in the wild does not meet these conditions.

\section{Animal feed}

- Biomass added to animal feed and sold as a commercial product is subject to the condition that the cultivation takes place in controlled and hygienic conditions. Asian knotweed that grows along tracks in the wild does not meet these conditions.

- If biomass first undergoes an extraction process and only the required pure extracted component, such as protein, is added to animal feed, the condition for controlled cultivation does not apply because the extraction process might prevent any pollution from ending up in the end product. The end product must be sufficiently pure to be used safely. Processing knotweed from rail environments could be an option if the relevant components (proteins) could be extracted at low costs, in sufficient amounts, and with sufficient purity before being used in animal feed. 


\section{Biorefinery}

No specific biorefinery applications for Asian knotweed were found. The summary below involves biorefinery examples of other plant species. For Asian knotweed the composition related to the fibre build-up and strength and such are unknown and requires further research.

- The processing and upgrading (biorefinery) of (roadside) cuttings and green refuse resulting from water management is fully in development and can offer leads for the processing of knotweed refuse. Whether knotweed can be processed and applied in the same way as grass cuttings must be further researched.

- Green refuse can serve as a raw material for the production of protein (technical applications), fibres (various application) and sap from which phosphate, sugar, minerals and salt can be extracted.

- Fibres resulting from extraction processes of green refuse streams such as roadside cuttings and elephant grass (Miscanthus) can be used as a raw material for various purposes such as paper, biocomposite and building materials.

- Natural bamboo is an example of a bio-based material used for construction purposes. Application options may be improved and expanded via specific pre-processing methods.

- Acetophenones are used in industrial applications such as the production of resins. Acetophenone is also found in Asian knotweed, although it is not known whether this specific type of acetophenone (tetrahydroxy-acetophenone) is suitable for this purpose.

\section{Composting/bokashi}

- Composting biomass results in a stable organic material that can be used as soil improver.

- Residual streams of Asian knotweeds can be composted and applied as soil improver without risk (under certification).

- Uncertainties currently exist about the added value and risks of Bokashi. It has yet to be proven that weed seeds and plant pathogens are effectively eliminated in Bokashi.

- Bokashi is not an approved soil improver at this time and cannot be sold and used as such. Bokashi produced on one's own grounds with one's own organic material can be used as soil improver.

\section{Energy}

- Due to its fast growth, knotweed is considered a potential energy source. Combined with other green refuse streams, the fermentation of knotweed could be an option for bio-gas production.

- Asian knotweed has a relatively stable and high content of biomass with an energy value similar to dry wood chips and wood pellets. It could be used to make fuel pellets. For a biomass yield of approximately $30 \mathrm{t} \mathrm{ha}^{-1} \mathrm{DM}$ this amounts to $583.32 \mathrm{GJ} \mathrm{ha}^{-1}$.

\section{Phytoremediation}

- Phytoremediation is a proven technology in which plants are used to immobilise or remove pollution from the soil.

- Asian knotweed is considered suitable for phytoremediation, and especially for soils polluted by zinc and cadmium, as long as it does not contribute to the further spread of knotweed.

\section{Volume streams}

- The acreage of Asian knotweed along the tracks is estimated at approx. 10 ha.

- The total amount of biomass above ground (stems and leaves) is generally between 100-250 tonnes DM per year. Annual harvesting will reduce this amount over time.

- The biomass of the rootstocks is estimated at around 150 tonnes DM.

\section{Knotweed control goals}

- It is ProRail's goal to eliminate Asian knotweed in the long term.

- The annual harvesting of knotweed biomass above ground preserves the knotweed stands and does not contribute to the elimination goal.

- The rootstocks could be harvested if a useful application of Asian knotweed is found. While equipment is available, the earth-moving activities are a major risk for further spreading of the knotweed via root and stem fragments. Earth-moving activities near the tracks may also affect the stability and settlement of the soil and disrupt water management. These effects often only become visible later and require after-care (Kouwenberg, pers. med.). Harvesting rootstocks can only be performed once and does contribute to the elimination goal.

- Equipment for removing rootstocks without earth-moving effects may need to be developed. 


\title{
$8 \quad$ Conclusions and recommendations
}

\author{
Human nutrition, medicinal applications and supplements \\ The results of this study show that knotweed is used for many purposes, including as traditional \\ (folklore) medicine in Asian countries. Medicinal extracts are extracted from the dried and finely \\ ground plant parts from above or below ground by adding hot water ('herbal tea') or an alcoholic \\ solution ('tincture'). Medicinal or health-related effects are mainly attributed to the plant components \\ resveratrol and emodin. Cell studies show that these components have an antimicrobial, anticancer, \\ antioxidant and anti-inflammatory effect, and protect brain functions and veins. Resveratrol in vitro is \\ even said to slow down infection by the MERS-CoV virus, a coronavirus similar to SARS-CoV, but \\ scientific evidence for the effectiveness in humans is lacking.
}

In Asian countries, knotweed is also used in cooking. Young shoots are eaten like asparagus or are used as a replacement of rhubarb due to their mild acidic flavour.

The fact that the young shoots are used for medicinal purposes and eaten in Asian countries does not automatically mean that this would be allowed in the EU. It would first require authorisation from the European Food and Safety Authority (EFSA). Obtaining authorisation requires scientific and technical proof that the novel food can be consumed safely, is not harmful to people who consume it, and does not contain any toxic components, anti-nutritional factors, allergens and/or contaminants. In addition, it must be shown that the new crop can be produced safely, which means cultivation takes place in controlled and hygienic conditions.

Asian knotweed that grows along tracks in the wild does not meet the condition of controlled and hygienic cultivation. Moreover, it is known that knotweed absorbs a relatively high amount of heavy metals from the soil. It can be assumed this would be the case in rail environments, minimising the chance that Asian knotweed can be used for human nutrition, medicinal purposes or the supplement market (in the short term, at least). The property does offer opportunities to remediate soil pollution along the tracks (phytoremediation).

\section{Animal feed}

Biomass added to animal feed and sold as a commercial product is subject to the condition that the cultivation takes place in controlled and hygienic conditions. If biomass first undergoes an extraction process and only the required pure extracted component, such as protein, is added to animal feed, the condition for controlled cultivation does not apply as the extraction process might prevent any pollution from ending up in the end product. This could allow the use of Asian knotweed, if the extraction is realised at sufficiently low costs to make use of the protein in animal feed economically viable.

\section{Biorefinery}

Biorefinery techniques enable biomass to be used as a raw material for the production of protein, fibre and sap from which phosphate, sugar, minerals and salt can be extracted. The development of this technology is ongoing, especially for the processing of (roadside) cuttings and biomass resulting from water management. No specific biorefinery applications for Asian knotweed were found. This does not mean that these developments do not create opportunities for the processing of knotweed, possibly combined with other green refuse resulting from track management. The current cutting which is common along the track and primarily focused on cost-efficient logistics would have to be reorganised. Developments in the field of precision agriculture (sensor technology, robotics, drones and autonomous vehicles) may also offer opportunities to optimise this process (see framework).

Concrete examples of products made from biomass on an experimental scale include paper and cardboard, insulation material, peat replacement, bio-composite for tree supports, shoring material, crash barriers and simple garden furniture. It is also processed in concrete for tiles, stairs and 
reinforcement plates for walking and cycling paths. Pre-processed bamboo is used as a construction material. Asian knotweed contains components that may be applicable in the production of resins and colourants. The application of bio-based products produced from 'own' green refuse contributes to ProRail's sustainability goals.

\section{Energy recovery}

Asian knotweed supplies a relatively high amount of biomass with an energy value similar to dry wood chips and wood pellets. Combined with other green refuse streams, knotweed biomass could be suitable for energy recovery via fermentation or incineration as pellets. Although harvesting the knotweed biomass above ground on a yearly basis would keep the growth locations intact, it would not contribute to the elimination goal.

\section{Phytoremediation}

Phytoremediation with Asian knotweed is a proven technology to immobilise or remove pollution from the soil. This especially applies to zinc, cadmium and copper-polluted soils. The principle of phytoremediation is based on the periodic removal of plant parts above ground in which the pollution has amassed. The growth location must generally remain intact for a longer period to do so. This is not in line with ProRail's elimination goal. Existing knotweed growth locations on polluted soil could be preserved to remediate the soil and removed at a later date once the soil levels have sufficiently recovered. There could be extra benefits if the plant parts above ground were to be harvested periodically, taking into account the accumulation of heavy metals, and used in a practical way.

\section{Volumes}

The amount of biomass from knotweed rootstocks is similar to that of potato tubers: approximately 15 tonnes of dry material per ha. In the Netherlands, however, some 80,000 hectares of consumption potatoes were grown in 2019 (CBS) while the acreage of knotweed around the tracks is estimated at around 10 ha. Based on the relatively small acreage of Asian knotweed, it is unlikely that viable processing can be set up. It would still not be viable if the acreage was 10 or even 100 times greater. Moreover, knotweed rootstocks can only be harvested once. This does contribute to ProRail's elimination goal.

Due to the dispersed growth locations, current situation and available equipment, the costs of 'harvesting' would be relatively high. A better business case could be established by combining possible applications of biomass and new technology in a clever way. Options include:

- Scaling up the harvestable volume of knotweed via a better survey along the tracks and increasing the collaboration with other managers of land with knotweed, or processing in combination with other green refuse like roadside cuttings.

- Using the knotweed locally to remediate the soil combined with the processing of resulting plant material into bio-based materials and products. This could be realised by joining ongoing initiatives for the processing of green refuse such as (roadside) cuttings, bamboo or elephant grass.

- Improving the 'harvesting techniques' for removing rootstocks and plant parts above ground. This could prevent issues (and costs) related to the stability and settlement of the soil, the disruption of the water management along the tracks, and the unintentional further spreading of the knotweed due to earth movement. 
Developments in the field of precision agriculture such as sensor technology, robotics, drones and autonomous vehicles offer opportunities for optimising the harvesting process of knotweed along the tracks.

Precision agriculture is a type of agriculture in which plants (or animals) receive exactly the treatment they need. The major difference with classic agriculture is that it determines the process per field, while precision agriculture determines it per square metre or plant. Precision agriculture is a data-intensive activity requiring remote and nearby sensors for observing crops, soil, pathogens and pests, weather conditions and more (observation). Based on the sensor values, specific software with decision-making rules and models determine the condition of the crop (or soil) and any deficiencies or needs (diagnostics) and, if so, which place-specific treatment is needed (decision). Finally, operational activities must be carried out, often led by equipment and (autonomous) machines (realisation). After evaluation, the chain starts again. For more information and examples, see: www. proeftuinprecisielandbouw.nl (Dutch only).

\section{Recommendations}

- Developments in the field of biorefinery create opportunities for the processing of knotweed in, for example, animal feed, possibly combined with other green refuse resulting from track management. We recommend joining ongoing initiatives.

- Fibres from green refuse are suitable as raw material for specific products like paper and cardboard, building materials and for use in constructions (analogous to bamboo). It is recommended to (have third parties) develop products from green refuse resulting from the current management around the tracks as this would contribute to ProRail's sustainability goals.

In addition, we recommend research into whether fibres from knotweed have the same properties and applications as fibres from (roadside) cuttings, bamboo and elephant grass. If so, these fibres could also be used in specific products.

- Find out whether energy recovery is possible and profitable by processing knotweed into fuel pellets or via fermentation, possibly combined with other green refuse streams.

- Knotweed must firstly be harvested before it can be applied. This harvest currently often involves large scale earth-moving activities, including all the related risks, and is relatively expensive. New technologies that involve as little earth-moving activities as possible are required. We recommend finding out if there are any developments in the field of sensor technology, robotics and autonomous vehicles in agriculture, for instance, which offer opportunities to optimise the process.

- Research whether the absorption of heavy metals by Asian knotweed can play a role in the remediation of soil pollution around the tracks (phytoremediation). Existing growth locations on polluted soils can be kept intact for phytoremediation purposes, while knotweed can be removed from unpolluted soils. Deliberately planting knotweed on polluted soils along the tracks to enable soil remediation is not recommended.

- Even if a useful application of Asian knotweed is found, it will remain difficult to establish a definitive business case based on the current acreage. Options to improve the business case include upscaling biomass and combining applications by:

- Increasing biomass volumes by cooperating with other terrain managers such as RWS, municipalities, provinces and district water boards, or seeking out international partnerships.

- Processing knotweed refuse in combination with other green refuse streams to create more volume. A condition will be reorganising the current cutting methods, which are primarily focused on cost-efficient logistics. 


\section{References}

Baker, A.J.M., and S.P. McGrath, C.M.D. Sidolib \& R.D. Reevesc, 1994. The possibility of in situ heavy metal decontamination of polluted soils using crops of metal-accumulating plants. Resources, Conservation and Recycling 11(1-4):41-49.

Berman, A.Y., Motechin, R.A., Wiesenfeld, M.Y., Holz, M.K., 2017. The therapeutic potential of resveratrol: a review of clinical trials. npj Precision Onc 1, 35.

Biomassa Alliantie, 2017. Waarde van maaisel. Circulair terreinbeheer in de praktijk. www. circulairterreinbeheer.nl.

Bobis, O., Dezmirean, D.S., Bonta, V., Moise, A., Pasca, C., Domokos, T.E., Urcan, A.C., 2019. Japanese Knotweed (Fallopia Japonica): Landscape Invasive Plant Versus High Quality Honey Source. Scientific Papers. Series D. Animal Science. Vol. Lxii, No. 1: 231-235.

Brinkman, A., 2014. Biogas uit gras - een onderbenut potentieel Een studie naar kansen voor grasvergisting. Brinkman Consultancy.

Brunerova, Anna, Miroslav Muller \& Milan Brozek, 2017. Potential of wild growing Japanese knotweed (Reynoutria japonica) for briquette production. Engineering for Rural Development 561-568.

Brock, J.H., 1994. Technical note: Standing crop of Reynoutria japonica in the autumn of 1991 in the United Kingdom. Preslia, 66: 337-343.

BVOR, 2017. Innovatief aanbesteden van groenafval en gras Een handreiking voor aanbestedende diensten. Branche Vereniging Organische Reststoffen (BVOR). www.bvor.nl.

Callahan, T.V., Scott, R., Lawson, G.J. and Manwaring, A.M., 1984. An experimental assessment of native and naturalised species of plants as renewable sources of energy III. Japanese knotweed Reynoutria japonica. Cumbria, UK: Institute of Terrestrial Ecology

Chaoji Chen, Zhihan Li, Ruiyu Mi, Jiaqi Dai, Hua Xie, Yong Pei, Jianguo Li, Haiyu Qiao, Hu Tang, Bao Yang and Liangbing Hu, 2020. Rapid Processing of Whole Bamboo with Exposed, Aligned Nanofibrils toward a High-Performance Structural Material. ACS Nano 14(5): 5194-5202.

Day, Laurence, Jessica Rall, Susan McIntyre and Charles Terrance, 2009. Japanese Knotweed Composting Feasibility Study, Delaware County (New York). Ecological Restoration, Vol. 27, No. 4, pp. 377-379.

Eliáš, P., 1998. Estimation of Reynoutria japonica Houtt. biomass in Slovakia. Acta Horticulturae at Regiotecturae Nitriae, 1: 3-4.

El-Readi, M.Z., Eid, S.Y., Al-Amodi, H.S., Wink, M., 2016. Fallopia japonica: Bioactive Secondary Metabolites and Molecular Mode of Anticancer. J Tradi Med Clin Natur 5:193

Fuchs, J.G., 2017. Studie zur Persistenz von Erdmandelgras (Cyperus esculentus) und Japanknöterich (Reynoutria japonica) in Kompostierungs- und Vergärungsprozessen FiBL Schweiz / Suisse.

Ghanim, Husan, Chang Ling Sia, Sanaa Abuaysheh, Kelly Korzeniewski, Priyanka Patnaik, Anuritha Marumganti, Ajay Chaudhuri, Paresh Dandona, 2010. An Antiinflammatory and Reactive Oxygen Species Suppressive Effects of an Extract of Polygonum Cuspidatum Containing Resveratrol, The Journal of Clinical Endocrinology \& Metabolism, 95, pp E1-E8.

Hulina, N. and Đumija, L., 1999. Ability of Reynoutria japonica Houtt. (Polygonaceae) to accumulate heavy metals. Periodicum Biologorum, Vol.101 No.3 pp.233-235.

Hulme, P.E., Bacher, S., Kenis, M., Klotz, S., Kuhn, I., Minchin, D., Nentwig, W., Olenin, S., Panov, V., Pergl, J., Pysek, P., Roques, A., Sol, D., Solarz, W., Vila, M., 2008. Grasping at the routes of biological invasions: a framework for integrating pathways into policy. Journal of Applied Ecology 45 (2): 403-414.

Hulme, P.E., 2009. Trade, transport and trouble: managing invasive species pathways in an era of globalization. Journal of Applied Ecology 46 (1): 10-18.

Jan, S. \& J.A. Parray, 2016. Phytoremediation: A Green Technology. Approaches to Heavy Metal Tolerance in Plants pp 69-87.

Kurita, S., Kashiwagi, T., Ebisu, T., Shumamura, T., and Ukeda, H., 2014. Content of resveratrol and glycoside and its contribution to the antioxidative capacity of Plygonatum cuspidatum (Itadori) harvested in Kochi. Bioscience, Biotechnology and Biochemistry 78:3, 499-502. 
Leferink, Jenneke, Johan van Valkenburg, Joyce Penninkhof en Chris van Dijk, 2020. Zaden bij Japanse duizendknoop! Kunnen ze kiemen en zich vestigen? Nature Today, 2 July 2020.

Lehtomäki, A., T.A. Viinikainen \& J.A. Rintala, 2008. Screening boreal energy crops and crop residues for methane biofuel production. Biomass and Bioenergy, 32(6): 541-550.

Oldenburger, Jan, Joyce Penninkhof, Casper de Groot en Fons Voncken, 2017. Praktijkproef bestrijding duizendknoop. Resultaten en kostenefficiëntie van zeven bestrijdingsmethoden voor duizendknoop en varianten daarop. Stichting Probos, Wageningen.

Macfarlane, J., 2011. Development of strategies for the control and eradication of Japanese knotweed. Thesis University of Exeter, UK.

Metličar, V., Vovk, I., Albreht, A., 2019. Japanese and Bohemian Knotweeds as Sustainable Sources of Carotenoids. Plants 8, 384.

Rahmonov, O., Czylok, A, Orczewska, A, Majgier, L. and Parusel T., 2014. Chemical composition of the leaves of Reynoutria japonica Houtt. and soil features in polluted areas. Cent. Eur. J. Biol. 9(3): 320-330. DOI: 10.2478/s11535-013-0267-9

Ramírez-Garza, S.L., Laveriano-Santos, E.P., Marhuenda-Muñoz, M., Storniolo, C.E., Tresserra-Rimbau, A., Vallverdú-Queralt, A., Lamuela-Raventós, R.M., 2018. Health Effects of Resveratrol: Results from Human Intervention Trials. Nutrients 10, 1892,

Rui, Wen, Wanxia Xia, Wei Zhao, Bingling Li, Jian Li, Yifan Feng, Hongyuan Chen \& Shujin Zhao, 2018. Quantitative Analysis of the Roots, Stems, and Leaves of Polygonum multiflorum by Ultra-HighPerformance Liquid Chromatography-Mass Spectrometry, Analytical Letters, 51:11, 1633-1641.

Singh, Har Bhajan, Kumar Avinash Bharati, 2014. In: Handbook of Natural Dyes and Pigments, ISBN 978-93-80308-54-8.

Strašil, Z. \& J. Kára, 2010. Study of knotweed (Reynoutria) as possible phytomass resource for energy and industrial utilization. Res. Agr. Eng., 56: 85-91.

Van Dijk, C.J., 2018. Proefsleuven spoortalud Kop Weespertrekvaart. Notitie Wageningen UR, 28 maart 2018. 7 pp.

Van Lieshout, D., N. Voets \& R. Verberne, 2019. Onderzoek potentie landelijk verwaarden maaisel Werkgroep Biomassa Energie- \& Grondstoffenfabriek. Ingenia Rapport 1858486-R06

Xian, C., Bardos, P. \& S. Robinson, 2011. Can composting kill Japanese Knotweed? University of Reading.

Zhang, Huan, Chang Li, Sin-Tung Kwok, Qing-Wen Zhang, and Shun-Wan Chan, 2013. A review of the pharmacological effects of the dried roots of Polygonum cuspidatum (Hu Zhang) and its constituents. Evidence-Based Complementary and Alternative Medicine 2013, pp 1-13.

Zhou, Y., Hou, Y., Shen, J., Huang, Y., Martin, W., Cheng, F., 2020. Network-based drug repurposing for novel coronavirus 2019-nCoV/SARS-CoV-2. Cell Discov 6, 14.

Zwart, K.B. \& Boer, D. de, 2015. Droge vergisting van berm- en natuurgras. Wageningen UR (University \& Research centre), Alterra-rapport 2661. 46 pp. 


\section{Annex 1 Elimination methods for Asian knotweed (general)}

The elimination of Japanese knotweed can be realised via various methods: mechanical, thermal, chemical or biological (Table A1-1). There are other methods in development (Table A1-2). Information on the implementation and pros and cons of the various methods is available via Kennisnetwerk Invasieve Exoten (www.invasieve-exoten.info - Dutch only).

Table A1-1 Common elimination methods for Asian knotweed.

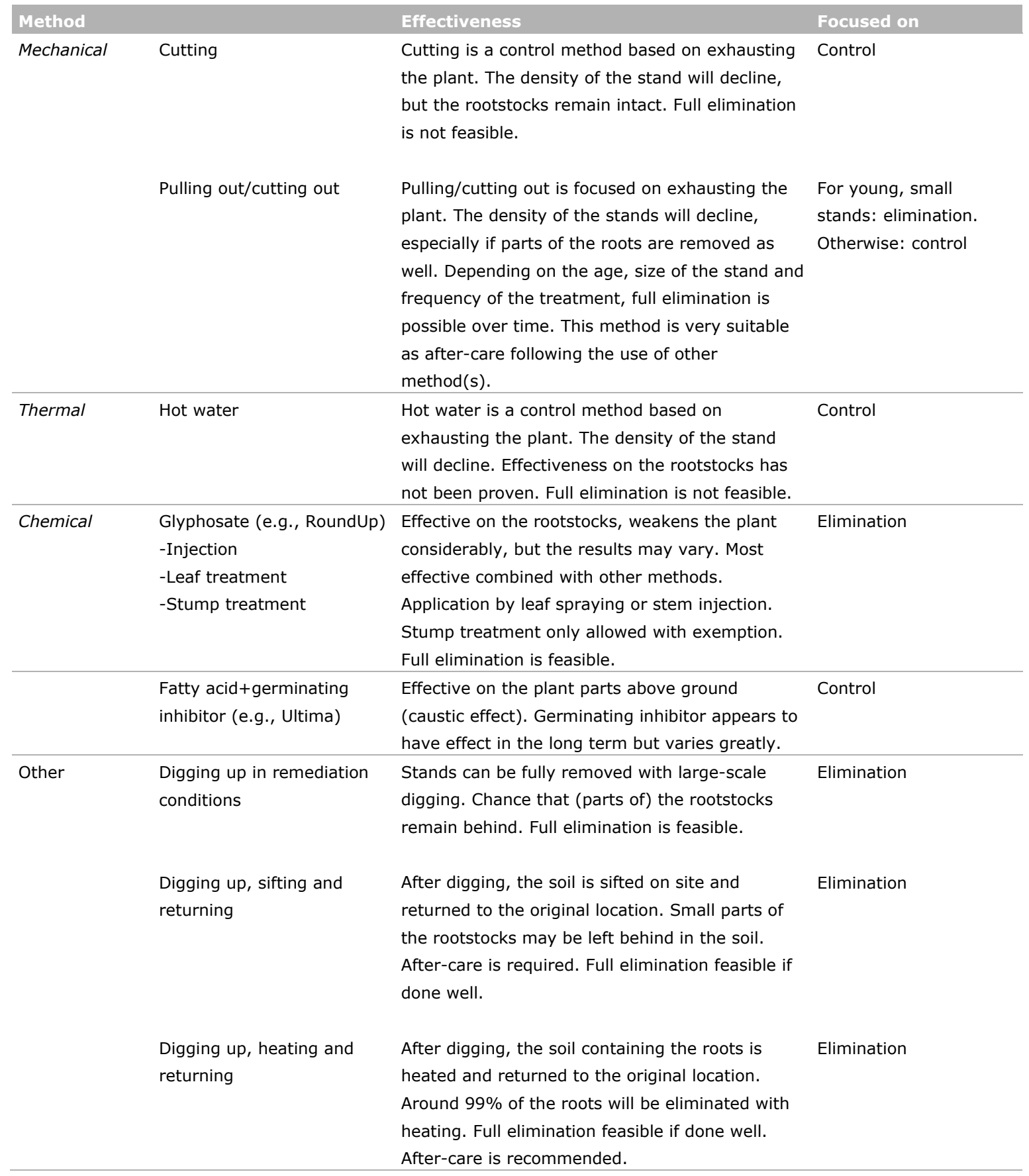


Covering up

After a long period of covering up the plants (at the plant staying away. Full elimination is feasible.

Grazing (sheep or pigs)

Pigs eat plants and rootstocks but have strong

Control preference for different plant species. Control method based on exhausting the plant. The density of the stand will decline, but the rootstocks remain largely intact. Full elimination is not feasible.

Table A1-2 Elimination methods for Asian knotweed in development

\begin{tabular}{lll} 
Method & Effectiveness & Focused on \\
Biological & Control method based on damaging the leaves. Control \\
& Good prospects but not yet available in NL. \\
\hline Japanese psyllid & Control method based on damaging the leaves. Control \\
& Good prospects but not yet available in NL. \\
\hline Other methods & There are various other methods for which the \\
& effectiveness has yet to be proven: \\
& Soil microwaving \\
& Shading \\
& Steaming \\
& Bruising and crushing \\
& UV radiation \\
& Liquid nitrogen \\
\end{tabular}


Corresponding address for this report:

\section{P.O. Box 16}

6700 AA Wageningen

The Netherlands

T +31 (0)317480700

www.wur.eu/plant-research

Report WPR-1004
The mission of Wageningen University \& Research is "To explore the potential of nature to improve the quality of life". Under the banner Wageningen University \& Research, Wageningen University and the specialised research institutes of the Wageningen Research Foundation have joined forces in contributing to finding solutions to important questions in the domain of healthy food and living environment. With its roughly 30 branches, 5,000 employees and 12,000 students, Wageningen University \& Research is one of the leading organisations in its domain. The unique Wageningen approach lies in its integrated approach to issues and the collaboration between different disciplines. 



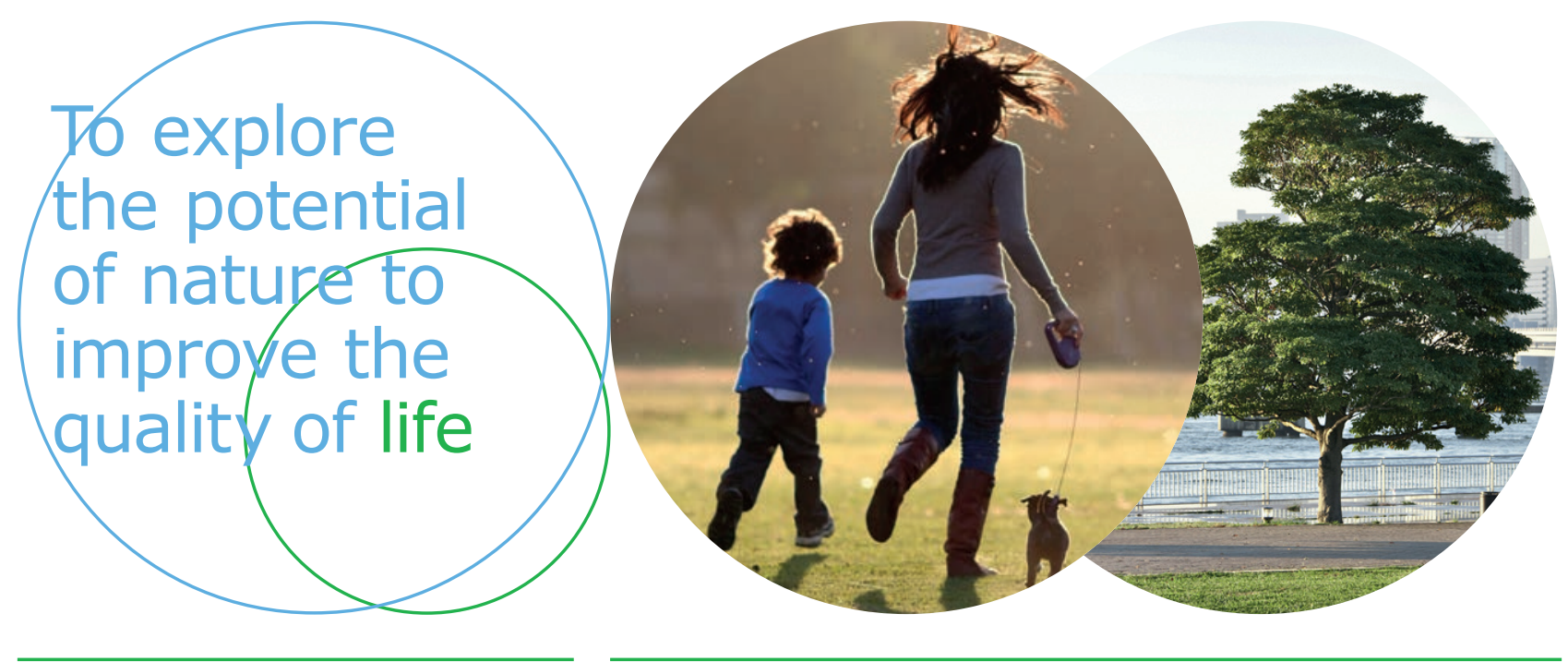

Corresponding address for this report:

P.O. Box 16

6700 AA Wageningen

The Netherlands

T +31 (0)317480700

www.wur.eu/plant-research

Report WPR-1004
The mission of Wageningen University \& Research is "To explore the potential of nature to improve the quality of life". Under the banner Wageningen University \& Research, Wageningen University and the specialised research institutes of the Wageningen Research Foundation have joined forces in contributing to inding solutions to important questions in the domain of healthy food and living environment. With its roughly 30 branches, 5,000 employees and 12,000 students, Wageningen University \& Research is one of the leading organisations in its domain. The unique Wageningen approach lies in its integrated approach to issues and the collaboration between different disciplines. 